\title{
Molecular Indicators of Sources and Biodegradation of Organic Matter in Sediments of Fluid Discharge Zones of Lake Baikal
}

\author{
Inna Morgunova ${ }^{1, *(\mathbb{D}}$, Petr Semenov ${ }^{1} \mathbb{D}$, Anna Kursheva ${ }^{1}$, Ivan Litvinenko ${ }^{1,2}$, Sergey Malyshev ${ }^{1}$, \\ Sergey Bukin $^{3}{ }^{(D}$, Oleg Khlystov ${ }^{3}$, Olga Pavlova ${ }^{3}$, Tamara Zemskaya ${ }^{3}$ (D) and Alexey A. Krylov ${ }^{1,2,3, *(1)}$
}

1 Federal State Budgetary Institution “Academician I.S. Gramberg All-Russian Scientific Research Institute for Geology and Mineral Resources of the Ocean” (FSBI “VNIIOkeangeologia”), 190121 St. Petersburg, Russia; petborsem@gmail.com (P.S.); a.kursheva@mail.ru (A.K.); ivanlitvinenko@mail.ru (I.L.); serg.i-karamba@yandex.ru (S.M.)

2 Institute of Earth Sciences, Federal State Budgetary Educational Institution of Higher Education "Saint-Petersburg State University", 199034 St. Petersburg, Russia

3 Limnological Institute, Siberian Branch, Russian Academy of Sciences, 664033 Irkutsk, Russia; sergeibukin@lin.irk.ru (S.B.); khloleg45@yandex.ru (O.K.); pavlova@lin.irk.ru (O.P.); tzema@lin.irk.ru (T.Z.)

* Correspondence: inik@list.ru (I.M.); akrylow@gmail.com (A.A.K.)

Citation: Morgunova, I.; Semenov, P.; Kursheva, A.; Litvinenko, I.;

Malyshev, S.; Bukin, S.; Khlystov, O.; Pavlova, O.; Zemskaya, T.; Krylov, A.A. Molecular Indicators of Sources and Biodegradation of Organic Matter in Sediments of Fluid Discharge Zones of Lake Baikal. Geosciences 2022, 12, 72. https:// doi.org/10.3390/geosciences12020072 Academic Editors: Hiroyuki Kitagawa and Jesus Martinez-Frias

Received: 21 November 2021

Accepted: 1 February 2022

Published: 4 February 2022

Publisher's Note: MDPI stays neutral with regard to jurisdictional claims in published maps and institutional affiliations.

Copyright: (C) 2022 by the authors. Licensee MDPI, Basel, Switzerland. This article is an open access article distributed under the terms and conditions of the Creative Commons Attribution (CC BY) license (https:// creativecommons.org/licenses/by/ $4.0 /)$.

\begin{abstract}
This paper performs a detailed study of a wide set of organic-geochemical proxies in 15 sediment cores collected from the main basins of Lake Baikal (the northern, the central and the southern) where processes of focused fluid discharge were detected. A variety of studied zones includes sites with gas and hydrothermal seepage, mud volcanoes with or without gas-oil fluid discharge, gas hydrates and authigenic carbonates. The composition of the dispersed organic matter and individual hydrocarbon molecular markers (n-alkanes, dimethyl alkanes, isoprenoids, steranes, terpanes and polycyclic aromatic hydrocarbons) testify to the input from predominantly allochthonous terrestrial and autochthonous microbial and algal sources. The studied sources, maturity and biodegradation parameters of organic matter vary significantly for areas with different fluid discharge. The composition of specific biomarkers including isoprenoids and immature hopanoids reflects the lateral and vertical changes of microbial activity in sediments associated with various environmental conditions. The identified types of terpanes distribution (mature, mixed and immature) correlate well with types of fluid discharge and attest to the development of various methanogenic and methanotrophic microbial communities in sediments. Moreover, the revealed specificity of microbial molecular markers distribution allowed us to suggest the fluid discharge processes in zones where they were not previously detected.
\end{abstract}

Keywords: dispersed organic matter; hydrocarbon molecular markers; sediments; fluid discharge zones; authigenic carbonates; gas hydrates; Lake Baikal

\section{Introduction}

Lake Baikal is a unique ultra-deep freshwater inland reservoir characterized by a variety of liquid and gas fluid discharge zones detected in the main deep basins (the northern, the central and the southern), submarine elevations and shallow water areas [1-5]. Discharge processes include hydrothermal venting (HTh), oil (OS) and gas (GS) seepage, mud volcanism (MV) and associated gas hydrate (GH) and authigenic carbonates (Carb) that form due to various diagenetic, catagenetic, endogenous and circulation processes in sediments of the Baikal Rift Zone [3,6-10]. The favorable environments of sediment accumulation (rapid sedimentation, large amount of terrigenous input, coastal erosion, discharges and landslides), their enrichment in organic matter, high primary production in water and microorganisms activity in sediments also determine such a diversity of fluid discharge zones [10-13]. 
The unique biodiversity of Lake Baikal is largely determined by the multiple changes in climatic, tectonic and geochemical processes that characterize the development of this region during ancient and modern geological epochs [4,14,15]. It is important to note that microorganisms play a key role in sedimentary biochemical processes. They are involved in the generation of hydrocarbons (HCs) and the active biological transformation of their dispersed and concentrated forms [13,16-19]. Thus, the importance of multidisciplinary research of the processes that occur in sediments of fluid discharge zones is hard to overestimate.

Hydrocarbon molecular markers (MM or biomarkers) are components of the dispersed organic matter (OM) and chemical fossils that inherit the chemical structure of their biological precursors and, thus, are a universal link in the chain of the sequential transformation of OM: biopolymers-biomonomers-geomonomers-geopolymers [20-23]. Their usage allows for the determination of the OM origin including the input from biogenic and abiogenic sources, the level of OM transformation during thermal maturation and biodegradation as well as the influence of endogenous and exogenous processes. The study of biogenic MM, products of the transformation of prokaryotic cell components in sediments of Lake Baikal, is of special interest. These proxies are effective for studying both the microbial production input to the sediments of zones with or without fluid discharge (background) and the type of microbial activity (HCs generation or biotransformation).

In this study, we present the results of the distribution of a wide set of organicgeochemical proxies in the bottom sediments of all the geographic zones of Lake Baikal (the northern, the central and the southern basin, Academician Ridge). Special attention is paid to the group composition of $\mathrm{OM}$ and the detailed study of its molecular composition (linear $n$-alkanes $n$-C14-n-C39 and branched 3,5-, 3,6-, 3,7-dimethylalkanes, isoprenoids, steranes, tri- and tetracyclic terpanes, hopanes, polycyclic aromatic HCs-PAHs; Table S1). A significant volume of actual data makes it possible to compare the organic-geochemical characteristics of sediments from zones with all the types of fluid discharge known in Lake Baikal: hydrothermal venting, mud volcanism and gas seepage, accompanied by the occurrence of gas hydrates, authigenic carbonates and oil. Moreover, the comparative study of areas with and without detected fluid discharge demonstrates a significant discrepancy in the group and molecular composition of OM. Thus, sampling across a wide range of underwater environmental conditions and the complex study of the origin of $\mathrm{OM}$ and transformation based on a wide set of molecular fingerprints provide a novel understanding of the geochemical state of bottom sediments of the fluid discharge zones of Lake Baikal. The study of organic-geochemical characteristics through the sediment section allows detecting the influence of different geological processes on OM biodegradation and microbial activity.

\section{Geological Setting of Lake Baikal Sampling Sites}

The northern Basin of Lake Baikal was sampled in the area of the low-temperature hydrothermal vent in Frolikha Bay (site 1, 2; Figure 1; Table 1; [18,24-29]) and in the background area near the Barguzinsky Nature Reserve (site 3; Figure 1; Table 1). The fluid discharge center of low-temperature hydrotherm (up to $16^{\circ} \mathrm{C}$ ) of Frolikha Bay is associated with regional active faults. Microbial mats, which cover the surface sediments in the area of seepage, consist predominantly of colorless sulfur bacteria of the genus Thioploca [26,30]. Methane-producing archaea [28] and methanotrophic bacteria [13] as well as various benthic organisms, hydrobionts and fish fauna, which form a unique biological community based on chemosynthesis $[18,25]$, were also found in the surface layer of sediments. The gas fluid consists predominantly of methane of mixed microbial-thermogenic origins (with the possible admixture of endogenous [7]). Sediments are enriched in sulfates due to the oxidation of sulfides by bacteria of the Thioploca genus [27]. The organic matter of bottom sediments has a low level of thermal maturity [31]. 
Cruise: 2017

2018

2019

2020

\section{BG - background station}

HTh - hydrothermal seepage

OD - oil discharge zone

$\mathrm{GH}$ - gas hydrate structure

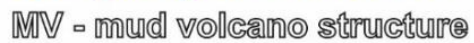

Carb. - authigenic carbonates

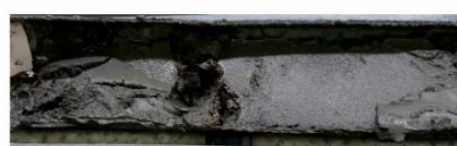

Oil channel (Gorevoy Utes, 7)

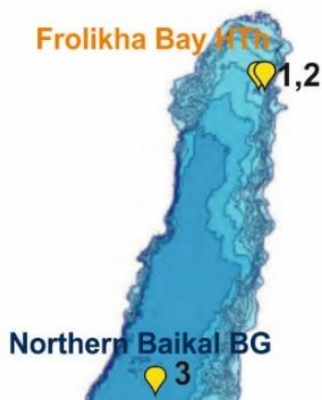

$08^{\circ}$

Ushkany Islands, BG $-250 \mathrm{~m}$

Academician Ridge

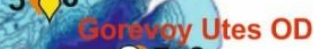

07,8

itami, NTV

$-750 m$

$-1000 m$

$-1250 m$

$-1500 m$

$-1642 m$

Gas hydrates (Kedr, 14)

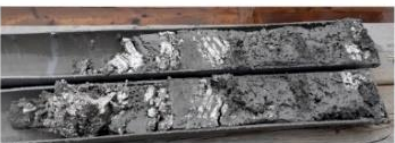

Figure 1. Sampling sites in the northern, central and southern basins of Lake Baikal classified by the type of the focus fluid discharge process and expeditionary year.

Table 1. Main characteristics of samples and their organic geochemical parameters.

\begin{tabular}{|c|c|c|c|c|c|c|c|c|c|c|c|}
\hline \multirow{2}{*}{$\begin{array}{c}\text { Core } \\
\#\end{array}$} & \multirow{2}{*}{$\begin{array}{l}\text { Sampling } \\
\text { Intervals, cm }\end{array}$} & \multicolumn{2}{|c|}{ Coordinates } & \multirow{2}{*}{ Lithological Description } & \multicolumn{3}{|c|}{ Content in Sediment, \% } & \multicolumn{4}{|c|}{ Content in OM, \% } \\
\hline & & $\mathbf{N}$ & W & & $\mathrm{CaCO}_{3}$ & TOC & OM & EOM1 & EOM2 & HA & ROM \\
\hline \multicolumn{12}{|c|}{ Northern Baikal } \\
\hline \multicolumn{12}{|c|}{ Frolikha Bay (low-temperature hydrothermal seep) } \\
\hline 1 & $n=2: 0-10 ; 25-35$ & 55.52 & 109.78 & $\begin{array}{l}\text { Diatomaceous silt with } \\
\text { hydrotroilite; }-/ /-\end{array}$ & $\frac{0.00-0.00}{0.00}$ & $\frac{0.6-0.9}{0.7}$ & $\frac{1.1-1.6}{1.3}$ & $\frac{2.3-2.6}{2.5}$ & - & - & - \\
\hline 2 & $n=2: 5-15 ; 137-147$ & 55.52 & 109.76 & $\begin{array}{c}-/ /-; \text { Turbidite with } \\
\text { sand layers }\end{array}$ & $\frac{0.00-0.33}{0.17}$ & $\frac{1.5-2.0}{1.8}$ & $\frac{2.8-3.6}{3.2}$ & $\frac{1.5-2.5}{2.0}$ & - & - & - \\
\hline 3 & $\begin{aligned} n=3: 5-15 ; 62-72 \\
110-120\end{aligned}$ & 54.46 & 109.06 & $\begin{array}{l}\text { kground area near the Bar } \\
\text { Oxidized layer, } \\
\text { silt with hydrotroilite; } \\
\text { silt with sand }\end{array}$ & $\begin{array}{l}\text { insky Natu } \\
\frac{0.00-0.33}{0.17}\end{array}$ & $\begin{array}{l}\text { Reserve } \\
\frac{0.5-1.5}{1.0}\end{array}$ & $\frac{0.9-2.7}{1.8}$ & $\frac{1.3-1.8}{1.6}$ & - & - & - \\
\hline \multicolumn{12}{|c|}{ Central Baikal } \\
\hline \multicolumn{12}{|c|}{ Background area near the Ushkany Islands (Fe-Mn crusts) } \\
\hline 4 & $\begin{array}{c}n=3: 0-3 ; 3-16 \\
16-27\end{array}$ & 53.88 & 108.61 & $\begin{array}{l}\text { Diatomaceous silt; -//-; } \\
\text { Oxidized clay layer } \\
\text { with hydrotroilite }\end{array}$ & $\frac{0.08-0.33}{0.22}$ & $\frac{0.2-1.2}{0.8}$ & $\frac{0.3-2.2}{1.5}$ & $\frac{0.3-1.9}{1.0}$ & $\frac{1.2-3.3}{2.2}$ & $\frac{0.0-22.0}{10.1}$ & $\frac{75.2-94.8}{86.7}$ \\
\hline 5 & $\begin{array}{c}n=3: 10-20 ; 40-50 ; \\
120-130\end{array}$ & 53.50 & 108.00 & $\begin{array}{c}\text { Academician Ridge } \\
\text { Mud volcanic breccia; } \\
\text {-//-; -//- } \\
\text { Academician Ridge, }\end{array}$ & $\begin{array}{l}\text { ud volcano } \\
\frac{0.00-0.17}{0.08} \\
\text { kground are }\end{array}$ & $\frac{0.8-0.9}{0.9}$ & $\frac{1.5-1.7}{1.6}$ & $\frac{1.1-1.2}{1.1}$ & $\frac{1.4-3.4}{2.4}$ & $\frac{4.6-11.0}{8.6}$ & $\frac{84.4-92.0}{87.9}$ \\
\hline
\end{tabular}


Table 1. Cont.

\begin{tabular}{|c|c|c|c|c|c|c|c|c|c|c|c|}
\hline \multirow{2}{*}{$\underset{\#}{\text { Core }}$} & \multirow{2}{*}{$\begin{array}{l}\text { Sampling } \\
\text { Intervals, cm }\end{array}$} & \multicolumn{2}{|c|}{ Coordinates } & \multirow{2}{*}{ Lithological Description } & \multicolumn{3}{|c|}{ Content in Sediment, \% } & \multicolumn{4}{|c|}{ Content in OM, \% } \\
\hline & & $\mathbf{N}$ & W & & $\mathrm{CaCO}_{3}$ & TOC & OM & EOM1 & EOM2 & HA & ROM \\
\hline 6 & $n=2: 5-15 ; 95-105$ & 53.50 & 108.07 & $\begin{array}{l}\text { Diatomaceous silty-clay } \\
\text { with hydrotroilite; -//- }\end{array}$ & $\frac{0.00-0.67}{0.33}$ & $\frac{1.3-2.0}{1.7}$ & $\frac{2.4-3.7}{3.0}$ & $\frac{1.1-1.3}{1.2}$ & - & - & - \\
\hline 7 & $\begin{array}{c}n=2: 10-20 \\
100-120\end{array}$ & 53.30 & 108.40 & $\begin{array}{l}\text { Gorevoy Utes, } \\
\text { Diatomaceous silt with oil; } \\
\text { Grey clay with oil }\end{array}$ & $\begin{array}{l}\text { seepage } \\
\frac{0.08-0.42}{0.25}\end{array}$ & $\frac{1.2-3.8}{2.5}$ & $\frac{2.3-6.9}{4.6}$ & $\frac{17.0-41}{29.2}$ & $\frac{33.9-7.1}{5.5}$ & $\frac{2.2-20.8}{11.5}$ & $\frac{49.4-58.3}{53.8}$ \\
\hline 8 & $\begin{array}{c}n=6: 0-15 ; 50-60 \\
60-70 ; 100-110 ; \\
\text { 190-200; 300-310 }\end{array}$ & 53.30 & 108.39 & $\begin{array}{c}\text { Diatomaceous silt with oil; } \\
\text { Diatomaceous silt; -//-; } \\
\text {-//-;Clay with } \\
\text { hydrotroilite; -//- } \\
\text { Kitami, mud }\end{array}$ & $\frac{0.08-0.33}{0.17}$ & $\frac{1.0-4.8}{2.5}$ & $\frac{1.8-8.7}{4.5}$ & $\frac{1.4-47.9}{12.1}$ & $\frac{1.9-5.9}{4.0}$ & $\frac{1.0-20.2}{11.4}$ & $\frac{38.4-90.0}{72.5}$ \\
\hline 9 & $n=2: 0-10 ; 110-120$ & 53.00 & 107.90 & $\begin{array}{l}\text { Silty clay; Silty clay } \\
\text { with GH }\end{array}$ & $\frac{0.17-0.17}{0.17}$ & $\frac{0.8-0.9}{0.9}$ & $\frac{1.5-1.7}{1.6}$ & $\frac{1.1-2.9}{2.0}$ & $\frac{1.6-2.8}{2.2}$ & $\frac{6.2-60.4}{33.3}$ & $\frac{36.9-88.1}{62.5}$ \\
\hline 10 & $n=2: 10-20 ; 50-65$ & 52.60 & 107.40 & $\begin{array}{l}\text { Cape Tolsty, oil } \\
\text { Diatomaceous silt with oil; } \\
\text { Grey clay }\end{array}$ & $\begin{array}{l}\text { eepage } \\
\frac{0.00-0.08}{0.04}\end{array}$ & $\frac{1.6-3.1}{2.4}$ & $\frac{3.0-5.7}{4.3}$ & $\frac{0.6-1.6}{1.1}$ & $\frac{0.8-2.1}{1.5}$ & $\frac{15.9-27.8}{21.9}$ & $\frac{68.5-82.6}{75.6}$ \\
\hline 11 & $\begin{array}{c}n=3: 0-15 ; 30-40 \\
86-96\end{array}$ & 52.59 & 106.73 & $\begin{array}{l}\text { Kukuy, mud volcano } \\
\text { Diatomaceous silt with } \\
\text { breccia; Clay with } \\
\text { carbonates; Clay with GH }\end{array}$ & $\begin{array}{l}\text { gas hydrates } \\
\frac{0.08-0.58}{0.28}\end{array}$ & $\frac{1.0-1.3}{1.2}$ & $\frac{1.9-2.4}{2.2}$ & $\frac{1.4-2.2}{1.7}$ & $\frac{1.6-4.3}{2.7}$ & $\frac{3.8-7.4}{11.0}$ & $\frac{76.9-92.5}{84.5}$ \\
\hline \multicolumn{12}{|c|}{ Southern Baikal } \\
\hline \multicolumn{12}{|c|}{ Posolsky canyon-1, hydrate hill } \\
\hline 12 & $\begin{array}{c}n=5: 5-15 ; 20-30 \\
86-96 ; 100-110 \\
193-203\end{array}$ & 52.00 & 106.00 & $\begin{array}{l}\text { Diatomaceous silt with } \\
\text { hydrotroilite; -//-; -//-; } \\
\text {-//-; Silty clay }\end{array}$ & $\frac{0.00-0.50}{0.22}$ & $\frac{1.0-2.7}{1.7}$ & $\frac{1.8-4.9}{3.0}$ & $\frac{0.9-1.6}{1.2}$ & $\frac{1.8-2.4}{2.1}$ & $\frac{4.9-22.4}{11.9}$ & $\frac{74.2-92.1}{84.8}$ \\
\hline \multicolumn{12}{|c|}{ Malenky, mud volcano } \\
\hline 13 & $\begin{array}{l}n=3: 0-15 ; 40-50 \\
80-90\end{array}$ & 51.92 & 105.63 & $\begin{array}{l}\text { Diatomaceous silt } \\
\text { with breccia; } \\
\text {-//-; Clay with pebbles }\end{array}$ & $\frac{0.08-0.08}{0.08}$ & $\frac{0.8-1.0}{0.9}$ & $\frac{1.4-1.9}{1.6}$ & $\frac{1.0-2.1}{1.6}$ & $\frac{2.6-4.4}{3.7}$ & $\frac{4.7-28.9}{17.1}$ & $\frac{67.5-86.9}{77.7}$ \\
\hline \multicolumn{12}{|c|}{ Kedr, mud volcano, gas hydrates } \\
\hline 14 & $\begin{array}{c}n=3: 10-20 ; 75-85 \\
120-135\end{array}$ & 51.60 & 104.90 & $\begin{array}{l}\text { Diatomaceous silt; Gas- } \\
\text { and water enriched clay; } \\
\text {-//- with carbonates } \\
\text { Diatomaceous silt with }\end{array}$ & $\frac{0.08-0.33}{0.19}$ & $\frac{0.7-1.6}{1.1}$ & $\frac{1.3-2.8}{2.0}$ & $\frac{0.8-1.3}{1.1}$ & $\frac{1.4-1.8}{1.6}$ & $\frac{0.8-8.8}{5.9}$ & $\frac{88.6-96.6}{91.4}$ \\
\hline 15 & $\begin{array}{c}n=6: 0-10 ; 20-30 \\
45-55 ; 95-105 ; \\
120-130 ; 166-174\end{array}$ & 51.61 & 104.90 & $\begin{array}{c}\text { hydrotroilite; }-/ /-; \text { Silty } \\
\text { clay with sand and } \\
\text { carbonates; }-/ /-;-/ /-(\text { no } \\
\text { carb.);-//- }\end{array}$ & $\frac{0.08-0.08}{0.08}$ & $\frac{0.5-1.2}{0.7}$ & $\frac{1.0-2.1}{1.3}$ & $\frac{0.6-1.3}{0.8}$ & $\frac{1.6-3.6}{2.2}$ & $\frac{4.3-13.5}{7.5}$ & $\frac{83.6-93.6}{89.5}$ \\
\hline
\end{tabular}

The first core collected from the Academician Ridge contains mud breccia (site 5 , Figure 1; Table 1; $[32,33])$ and the second is from the background area without any detected signs of deep fluid migration (site 6, Figure 1; Table 1). Hemipelagic sediment accumulation in this and other basins of the lake is supplied by the significant input of products of aquatic plants like phytoplankton and diatoms $[7,34,35]$. Sediments from the area of mud volcanic activity ("AcademRidge" [32]) are enriched with gas and contain gas hydrate layers and mud volcanic breccia of late Miocene-early Pliocene age. However, the ubiquitous overlapping of sediments with the thick layer of Holocene diatomic silt indicates the absence of modern volcanic activity. The study of microbial diversity in sediments of the region has revealed organotrophic, thionic, sulfate-reducing bacteria and methanogenic archaea. It is important to note that the last one is found at all the depths studied (up to $100 \mathrm{~m})$, except the lowest layer [36].

Sediments from the central Basin were collected from sites with liquid oil discharge (site 7, 8-Gorevoy Utes and site 10-Cape Tolsty; Figure 1; Table 1; [37-41]), gas seeps and mud volcanoes, where gas hydrates were detected (mud volcano Kitami-site 9 and Kukuy-site 11; Figure 1; Table 1; [42,43]). Oils from the discharge zones of the central and the southern Baikal are generally well studied and their composition is comparable to those of the Cretaceous and earlier ages (most likely the Oligocene-Early Miocene) from other deep-sea freshwater reservoirs [39,40]. Liquid oil discharges to the water as a consequence of vertical migration along the permeable zones of tectonic faults [44]. It forms bitumen mounds at the lake bottom and slicks on its water surface that are rapidly transformed by local oil-oxidizing bacteria [42,45]. Sediments in zones of oil discharge are permeated with oil channels and enriched with gas (predominantly methane of thermogenic origin with a small admixture of microbial). The main source of Baikal oil is OM of freshwater reservoirs with a high content of land plant components. Biological diversity in zones of oil discharge 
forms due to the growth of macro- and meiofaunal communities and microorganisms, which use HCs as a main carbon source $[13,18]$.

The studies of methane fluid discharge in the central and the southern basins of the lake evidence the predominantly microbial origin of gas [7,43]. Several hydrate-bearing mud volcanoes were detected in the area of Kukuy canyon [3,46]. While methane, seeping in the discharge zone, is predominantly thermogenic, in the adjacent area, it may have a mixed microbial-thermogenic origin. The same mixed genesis is also characteristic for methane from the gas hydrate-bearing Kitami mud volcano [7,47].

The study of the southern basin included the sampling of sediments from the mud volcano Malenky (site 13, Figure 1, Table 1; [6,7,13,28,48-50]) and gas hydrate-bearing sediments from the mud volcano Kedr (site 14, 15, Figure 1, Table 1; [49,51,52]). The former study of gas fluid from the MV Malenky [6] has suggested its possible migration from the deep strata. However, the analysis of isotopic carbon and nitrogen composition of benthic animals has revealed their vital dependence on the methane carbon source [18], and the study of the isotopic composition of methane has indicated its microbial origin [7]. Gas hydrates and authigenic carbonates were detected in sediments of the MV Kedr. It was also shown that the area around the MV has moundy bottom relief with pockmarks, which testify to the gas fluid discharge from greater depths [52]. Moreover, the coal-bearing beds of the Tankhoy Formation of the Oligocene-Miocene age in this part of the lake may serve as a source of gas for hydrates formation. Methane and its homologues associated with gas hydrates of the MV Kedr have a thermogenic or secondary-microbial genesis that differs from the other hydrate-bearing zones of the lake due to the active biodegradation processes. These data are consistent with the presence of molecular markers of anaerobic methanotrophic archaea in sediments [49].

One more sediment core from the southern basin of the lake is located to the south of the Selenga river delta (site 12, Figure 1; Table 1) in the region of the gas hydrate mound (Posolsky Canyon-1; [47]) near the Posolsk Bank where methane seeps and gas hydrates were detected $[3,7,13,17,49,50,53-55]$. According to the studies of the focused fluid discharge zone in this area, methane has a mixed thermogenic-microbial origin [7]. Results of the radioisotope research have shown the presence of both aerobic and anaerobic methane oxidation processes in the Posolsk Bank sediments $[17,56]$. The detected archaea genus Methanoperedenaceae (ANME 2d) and bacterial phylum Methylomirabilota (NC10) are the most possible microbes for the aerobic methane oxidation in this and other regions of Lake Baikal. This process is often accompanied by nitrate, nitrite, Fe(III) or Mn (IV) reduction [49].

\section{Materials and Methods}

\subsection{Sample Collection and Pretreatment}

Sediment samples for the study were collected during several scientific research cruises of LIN SB RAS onboard the R/V “G.Yu. Vereshchagin" to Lake Baikal in 2017-2020 (15 cores, 47 samples; Figure 1; Table 1). The data were classified according to the geographical position of stations and the absence or presence of detected fluid discharge near sampling sites. The cores collected from zones where fluid discharge was not detected we have considered as a background. Sediment samples were collected using a $3 \mathrm{~m}$ gravity corer with a plastic liner (i.d. $100 \mathrm{~mm}$ ). All the cores were sampled according to the lithological structure. Samples were kept in sterile boxes at $-18{ }^{\circ} \mathrm{C}$ until the laboratory investigation. Sample preparation included freeze-drying (Scanvac CoolSafe Freeze Dryer), grinding (Retsch RM-200), sieving to a fraction of $0.25 \mathrm{~mm}$ (Retsch AS-200) and taking $100 \mathrm{~g}$ of averaged subsamples (25\%) for OM extraction.

\subsection{Organic-Geochemical Analysis}

Details of the analytical procedure have been described in $[23,57,58]$ and can be summarized as follows: the content of organic (TOC) and carbonate $\left(\mathrm{CaCO}_{3}\right)$ carbon definition; Soxhlet extraction of the dissolved part of dispersed OM from sediments with chloroform 
(EOM1-non-polar extractable organic matter) and sulfur removing; Soxhlet re-extraction of sediments with ethanol/benzene $(1: 2 \mathrm{v} / \mathrm{v})$ for polar components of organic matter elicitation (EOM2); humic acids (HAs) extraction and calculation of the part of insoluble residual organic matter (ROM). The study of group composition of EOM1 included its fractionation into oils (hydrocarbons-HCs), resins and asphaltenes, and further oils fractionation into aliphatic (saturated-SAT) and aromatic (AR) components. The molecular composition of HCs (n-alkanes, isoprenoids, dimethylalkanes, tri- and tetracyclic terpanes, hopanes, steranes and polycyclic aromatic hydrocarbons-PAHs; Table S1) were studied using the method of gas chromatography-mass spectrometry (GC-MS) carried out on an HP5973/HP6850 Agilent Technologies MSD [57,58]. All compounds were assigned by the comparison of their retention times and mass spectra with those of external standards (Supelco 47,930-U, 46955-U, 49451-U; Chiron AS 2634.27-5UG, AS 0613.30-100-10, AS 2616.31-10UG, AS 2635.27-5UG, AS 0976.29-10-IO, AS 2646.30-10UG, AS 9876.16-50-IO, AS 9877.16-50-IO, AS 1693.16-500-IO, AS 0651.20-K-IO, S-4063-100-5 T), NIST and WILEY libraries and/or with published data [59-63].

\section{Results and Discussion}

\subsection{Group Composition of the Extractable Organic Matter}

The studied sediments from the northern, central and southern Basin of Lake Baikal are represented predominantly by diatomaceous silts typical for the modern Holocene sedimentation. The age of the bottom layers of cores from the Academician Ridge is an exception and is theoretically estimated as the Late Pleistocene due to the low sedimentation rates in the region (ca. $0.09 \mathrm{~mm} /$ year; $[11,64]$ ). However, the real age of sediments in cores collected from zones of fluid discharge, and especially regions with mud volcanic activity, may differ from the theoretical estimation due to the upward migration of the ancient rock material to the bottom surface. The importance of this phenomenon is confirmed by numerous findings of mud breccia inclusions in the studied sediment sections. The wide distribution of diagenetic iron sulfide inclusions (hydrotroilite) in the studied cores indicates processes of sulfate reduction, that in Lake Baikal are associated predominantly with a high methane concentration and its generation in sediments [65-67]. Special attention should be paid to the sediment cores with oil inclusions (site $7,8,10$ ), authigenic carbonates and gas hydrates (site $9,11,14,15)$ collected from the zones with focused fluid discharge.

The content of carbonate carbon $\left(\mathrm{CaCO}_{3}\right)$ in sediments is less than $0.67 \%$ (Table 1 ) that is associated with low content and lability of biogenic $\mathrm{CaCO}_{3}$ in the water column of the lake [68]. The concentration of TOC and OM varies from 0.2 to $4.8 \%$ and from 0.3 to $8.7 \%$, correspondingly (Table 1), reaching the expected maximum in oil-bearing layers of sediments from Gorevoy Utes and Cape Tolsty, and also in sediments from the hydrothermal zone of the Frolikha Bay. Significant variations in the group composition of OM (EOM1 from 0.3 to $47.9 \%$ and ROM from 96.6 to $36.9 \%$; Table 1 ) also reflect the difference between sites with fluid discharge and/or high bioproductivity from the background regions. In contrast to oil-bearing sediments, where the decrease of ROM is accompanied by the growth of the EOM1, the deep layers of the core from MV Kitami show the sharp increase of HAs (up to $60 \%$ ). This agrees with the upward migration of clay deposits enriched in terrigenous $\mathrm{OM}$ in the area of mud volcanism. This conclusion agrees with the relatively high concentrations of HAs in the surface sediments of mud volcanoes Malenky, Kukuy and Kedr, where the presence of mud breccia was detected. The ratio EOM1/EOM2 is less than one in most of the samples, except oil-bearing sediments, and indicates the input of oxidized OM with a relatively low level of thermal maturity $[69,70]$.

The content of TOC-normalized EOM1 ( $\beta$; Table 2 ) shows values less than $6 \%$ in most of the samples attesting to the syngenetic type of bituminous components of OM and the host rock $[69,71,72]$. The exception is sediments enriched in oil (sites 7 and 8), where bituminous components are of epigenetic origin ( $\beta$ up to 86\%). Oils (HCs) and resins dominate in the group composition of the EOM1 in most samples. The proportion of 
aliphatic fraction in $\mathrm{HC}$ composition is higher than aromatic (Al/ $\mathrm{Ar}>1$ ), attesting to the general uniformity of OM sources in the lake sediments.

\subsection{Geochemical Characteristic of Molecular Markers}

\subsubsection{N-Alkanes and Isoprenoids}

The total content of molecular markers (n-alkanes, steranes, terpanes, PAHs) varies significantly (from 271 to $10977 \mathrm{ng} / \mathrm{g}$ dry weight (dw); Table 2) depending on the geographic location and presence/absence of signs of the fluid discharge. The relatively high content is detected in zones of the oil show (site 8), mud volcanism (site 11,13,14), hydrothermal venting (site 1,2) and in the surface sediments of the hydrate hill (site 12), where the active fluid discharge is not detected. Herewith, different components lead to an increase in the total content of molecular markers. Thus, n-alkanes predominate in the composition of MM from mud volcanoes Kukuy, Malenky, Kedr, and in the region of the hydrate hill Posolsky canyon-1. Terpanes show maximum content in sediments from Frolikha Bay and oil show Gorevoy Utes (site 8). PAHs are the main components in some layers of the cores from MV Malenky and Gorevoy Utes (site 7), where the total content of MM is relatively low.

Most $n$-alkane profiles show a bimodal distribution with a significant predominance of high molecular weight (HMW) components $n-C_{27}-n-C_{31}$ of terrigenous origin-foliar, conifer plants and grass (TAR > 1; Table 2; [73-75]) and with relatively low maturity level $\left(\mathrm{CPI}_{22-30}>2\right.$ in most samples, except site 7, 8; Figure 2; Table 2). The growth of $\mathrm{n}-\mathrm{C}_{16}$ and $\mathrm{n}$ $\mathrm{C}_{18}$ homologues in the composition of the low molecular weight (LMW) n-alkanes in most studied sites (OEP17-19 < 1; Table 2) may attest to the processes of microbial transformation of algal detritus or the input of microbial OM [76-79]. Herewith, the possibility of evennumber n-alkanes input with petroleum HCs is extremely low due to the absence of their maximum in the studied profiles of oil-bearing sediments.

Table 2. Main organic-geochemical parameters of $\mathrm{OM}$ and its molecular components.

\begin{tabular}{|c|c|c|c|c|c|c|c|c|c|c|c|c|c|c|c|c|c|}
\hline $\begin{array}{l}\text { Core } \\
\#\end{array}$ & $\begin{array}{l}\text { Sampling } \\
\text { Interval, cm }\end{array}$ & $\beta, \%{ }^{1}$ & $\begin{array}{c}\% \text { i } \\
\text { EOM } \\
\text { HCs }\end{array}$ & $\begin{array}{l}\text { n } \\
\text { I1 }{ }^{2} A \\
\text { Resins }\end{array}$ & $\underset{S}{\mathrm{Al} / \mathrm{Ar} \mathbf{r}^{3}}$ & $\underset{\mathrm{ng} / \mathrm{g}}{\sum^{4}}$ & n-Alk. & $\begin{array}{l}\text { from } \\
\text { Ster. }\end{array}$ & $\begin{array}{c}\text { MM }^{5} \\
\text { Terp. }\end{array}$ & PAH & $\operatorname{Pr} / \mathrm{Ph}^{6}$ & $\begin{array}{l}\mathrm{OEP}^{7} \\
17-19\end{array}$ & $\begin{array}{l}\text { OEP } \\
27-31\end{array}$ & TAR $^{8}$ & $\mathrm{CPI}^{9}$ & $\begin{array}{l}\operatorname{Ret}^{10} \\
\% \sum \text { PAH }\end{array}$ & MPI1 ${ }^{11}$ \\
\hline \multicolumn{18}{|c|}{ Northern Baikal } \\
\hline \multicolumn{18}{|c|}{ Frolikha Bay (low-temperature hydrothermal seep) } \\
\hline \multirow[t]{2}{*}{1} & $0-10$ & 4.2 & 11.3 & 76.1 & 8.5 & $\begin{array}{c}2 \\
486.8\end{array}$ & 34.7 & 0.0 & 55.0 & 10.3 & 0.8 & 0.7 & 6.0 & 9.8 & 5.2 & 0.0 & 0.3 \\
\hline & $25-35$ & 4.7 & 13.2 & 76.1 & 1.5 & $\begin{array}{c}2 \\
486.8\end{array}$ & 38.5 & 0.0 & 49.6 & 12.0 & 0.8 & 0.8 & 5.9 & 5.9 & 4.9 & 0.0 & 0.3 \\
\hline \multirow{2}{*}{2} & $5-15$ & 2.7 & 8.8 & 82.5 & 8.1 & $\begin{array}{c}2 \\
564.7\end{array}$ & 73.7 & 0.0 & 14.8 & 11.5 & 0.9 & 0.5 & 5.5 & 4.7 & 3.9 & 1.4 & 0.3 \\
\hline & $137-147$ & 3.6 & 7.7 & 83.1 & 1.0 & $\begin{array}{c}1 \\
433.1\end{array}$ & 67.9 & 0.0 & 22.1 & 10.0 & 0.9 & 0.7 & 6.9 & 13.1 & 4.9 & 0.5 & 0.2 \\
\hline \multicolumn{18}{|c|}{ Background area near the Barguzinsky Nature Reserve } \\
\hline \multirow{3}{*}{3} & $5-15$ & 2.4 & 37.2 & 61.9 & 9.2 & $\begin{array}{c}1 \\
182.9\end{array}$ & 67.5 & 0.4 & 3.5 & 28.6 & 1.0 & 0.5 & 3.8 & 2.0 & 2.3 & 3.4 & 0.3 \\
\hline & $62-72$ & 3.3 & 10.5 & 80.0 & 6.0 & $\begin{array}{c}1 \\
425.3\end{array}$ & 72.4 & 0.0 & 8.0 & 19.5 & 1.0 & 0.5 & 4.2 & 3.4 & 2.2 & 1.8 & 0.3 \\
\hline & $110-120$ & 2.7 & 19.2 & 79.4 & 6.0 & 878.7 & 82.6 & 0.0 & 1.4 & 16.0 & 1.1 & 0.6 & 5.3 & 2.2 & 2.8 & 2.4 & 0.4 \\
\hline \multicolumn{18}{|c|}{ Central Baikal } \\
\hline \multicolumn{18}{|c|}{ Background area near the Ushkany Islands (Fe-Mn crusts) } \\
\hline \multirow{3}{*}{4} & $0-3$ & 1.2 & 20.3 & 75.7 & 2.7 & $\begin{array}{c}1 \\
836.9\end{array}$ & 89.9 & 0.1 & 6.9 & 3.2 & 1.4 & 0.9 & 6.1 & 9.4 & 3.1 & 6.1 & 0.6 \\
\hline & $3-16$ & 0.6 & 34.1 & 61.4 & 2.5 & $\begin{array}{c}1 \\
479.0\end{array}$ & 94.6 & 0.4 & 2.7 & 2.4 & 0.8 & 0.8 & 6.8 & 7.3 & 3.0 & 14.4 & 0.9 \\
\hline & $16-27$ & 3.5 & 36.8 & 52.7 & 5.5 & $\begin{array}{c}1 \\
584.1\end{array}$ & 93.0 & 0.2 & 4.2 & 2.8 & 1.1 & 0.9 & 4.9 & 9.2 & 2.8 & 8.5 & 0.8 \\
\hline \multicolumn{18}{|c|}{ Academician Ridge, mud volcano } \\
\hline \multirow{3}{*}{5} & $10-20$ & 2.1 & 15.7 & 81.7 & 2.6 & 902.6 & 54.3 & 0.0 & 4.0 & 41.8 & 3.0 & 0.5 & 6.2 & 15.2 & 3.4 & 0.4 & 0.5 \\
\hline & $40-50$ & 2.2 & 17.2 & 80.2 & 1.7 & 859.5 & 55.6 & 0.0 & 4.1 & 40.3 & 2.7 & 0.4 & 5.6 & 13.2 & 3.2 & 0.8 & 0.6 \\
\hline & $120-130$ & 1.9 & $15 . \overline{5}$ & 82.9 & 3.8 & 959.2 & 56.8 & 0.0 & 4.2 & 39.0 & 2.6 & 0.5 & 5.6 & 14.6 & 3.3 & 0.4 & 0.4 \\
\hline \multicolumn{18}{|c|}{ Academician Ridge, background area } \\
\hline \multirow[t]{2}{*}{6} & 5-15 & 2.3 & 19.0 & 79.9 & 7.3 & $\begin{array}{c}1 \\
472.3\end{array}$ & 72.3 & 0.2 & 5.1 & 22.3 & 1.1 & 0.5 & 4.3 & 4.8 & 2.6 & 2.2 & 0.3 \\
\hline & 95-105 & 2.0 & 19.1 & 79.4 & 6.2 & $\begin{array}{c}2 \\
168.3\end{array}$ & 69.3 & 0.3 & 6.5 & 24.0 & 0.9 & 0.5 & 4.6 & 3.9 & 2.7 & 1.6 & 0.4 \\
\hline
\end{tabular}


Table 2. Cont.

\begin{tabular}{|c|c|c|c|c|c|c|c|c|c|c|c|c|c|c|c|c|c|}
\hline \multirow{2}{*}{$\underset{\#}{\text { Core }}$} & \multirow{2}{*}{$\begin{array}{l}\text { Sampling } \\
\text { Interval, cm }\end{array}$} & \multirow{2}{*}{$\beta, \%^{1}$} & \multicolumn{2}{|c|}{$\begin{array}{c}\% \text { in } \\
\text { EOM1 }\end{array}$} & \multirow{2}{*}{${ }_{\mathrm{s}}^{\mathrm{Al} / \mathrm{Ar}{ }^{3}}$} & \multirow{2}{*}{$\underset{\text { ng/g }}{\sum M^{4}}$} & \multicolumn{3}{|c|}{$\%$ from $\Sigma M^{5}$} & \multirow[b]{2}{*}{ PAH } & \multirow{2}{*}{$\mathbf{P r} / \mathbf{P h}^{6}$} & \multirow{2}{*}{$\begin{array}{l}\text { OEP }^{7} \\
17-19\end{array}$} & \multirow{2}{*}{$\begin{array}{l}\mathrm{OEP}^{7} \\
27-31\end{array}$} & \multirow{2}{*}{ TAR $^{8}$} & \multirow{2}{*}{$\mathrm{CPI}^{9}$} & \multirow{2}{*}{$\begin{array}{l}\text { Ret }^{10} \\
\% \sum \text { PAH }\end{array}$} & \multirow{2}{*}{ MPI1 ${ }^{11}$} \\
\hline & & & HCs & Resins & & & n-Alk. & Ster. & Terp. & & & & & & & & \\
\hline \multicolumn{18}{|c|}{ Gorevoy Utes, oil seepage } \\
\hline \multirow[t]{4}{*}{7} & $10-20$ & 30.9 & 52.1 & 45.2 & 1.2 & $\begin{array}{c}1 \\
066.6\end{array}$ & 16.6 & 1.9 & 18.4 & 63.0 & 1.6 & 0.8 & 1.7 & 3.4 & 1.4 & 0.0 & 1.2 \\
\hline & $100-120$ & 75.2 & 50.8 & 46.1 & 4.6 & 801.2 & 5.7 & 0.9 & 8.9 & 84.5 & 3.2 & 0.6 & 0.5 & 0.1 & 1.4 & 0.0 & 1.3 \\
\hline & $0-15$ & 87.2 & 57.9 & 36.5 & 1.2 & $\begin{array}{c}3 \\
610.1\end{array}$ & 33.2 & 2.4 & 48.2 & 16.2 & 0.0 & 1.5 & 0.4 & 5.6 & 1.3 & 0.0 & 0.3 \\
\hline & $50-60$ & 12.0 & 64.7 & 33.8 & 2.0 & $\begin{array}{c}10 \\
976.8\end{array}$ & 51.0 & 2.0 & 44.4 & 2.6 & 0.0 & 1.9 & 0.8 & 16.5 & 2.0 & 0.0 & 0.3 \\
\hline \multirow{4}{*}{8} & $60-70$ & 20.7 & 67.6 & 29.8 & 1.6 & $\begin{array}{c}2 \\
475.9\end{array}$ & 14.4 & 3.5 & 69.9 & 12.2 & 2.2 & 2.1 & 0.7 & 1.4 & 2.1 & 2.3 & 0.0 \\
\hline & $100-110$ & 2.6 & 23.0 & 70.9 & 2.5 & $\begin{array}{c}2 \\
966.9\end{array}$ & 68.3 & 0.2 & 17.7 & 13.8 & 1.3 & 2.5 & 1.1 & 14.6 & 2.7 & 2.4 & 0.3 \\
\hline & 190-200 & 5.9 & 27.4 & 69.6 & 2.3 & $\begin{array}{c}3 \\
797.5\end{array}$ & 71.4 & 0.4 & 17.8 & 10.4 & 1.6 & 3.0 & 1.0 & 11.7 & 2.6 & 0.6 & 0.3 \\
\hline & $300-310$ & 3.8 & 19.8 & 71.8 & 3.0 & $\begin{array}{c}4 \\
969.4\end{array}$ & 77.8 & 0.3 & 13.7 & 8.3 & 1.4 & 3.4 & 1.2 & 19.3 & 2.9 & 0.4 & 0.9 \\
\hline \multicolumn{18}{|c|}{ Kitami, mud volcano } \\
\hline 9 & $0-10$ & 5.3 & 12.7 & 86.4 & 3.3 & $\begin{array}{c}1 \\
5368\end{array}$ & 59.2 & 0.3 & 9.1 & 31.4 & 1.7 & 0.5 & 7.1 & 13.8 & 3.8 & 0.0 & 0.4 \\
\hline & $110-120$ & 2.1 & 9.2 & 89.3 & 3.0 & $\begin{array}{c}1 \\
458.3 \\
\end{array}$ & 85.0 & 0.0 & 1.2 & 13.8 & 1.6 & 1.4 & 10.2 & 16.5 & 5.5 & 0.0 & 0.5 \\
\hline & & & & & & & Cap & e Tolst & oil seep & & & & & & & & \\
\hline 10 & $10-20$ & 2.9 & 10.4 & 84.9 & 4.0 & $\begin{array}{c}2 \\
531.5\end{array}$ & 67.0 & 0.4 & 4.6 & 28.0 & 1.2 & 0.6 & 6.9 & 17.0 & 4.5 & 0.0 & 0.4 \\
\hline 10 & $50-65$ & 1.1 & 22.1 & 75.8 & 1.9 & 747.4 & 48.6 & 0.5 & 16.3 & 34.6 & 1.8 & 0.5 & 7.0 & 13.9 & 4.1 & 0.0 & 0.4 \\
\hline & & & & & & Kukuy, & mud vo & Icano, & as hydr & es, cark & onates & & & & & & \\
\hline & $0-15$ & 2.6 & 10.1 & 87.6 & 5.3 & $\begin{array}{c}7 \\
826.2\end{array}$ & 89.2 & 0.0 & 2.3 & 8.5 & 1.4 & 1.0 & 8.2 & 41.8 & 4.0 & 0.3 & 0.5 \\
\hline 11 & $30-40$ & 4.0 & 12.6 & 85.8 & 10.3 & $\begin{array}{c}8 \\
116.5\end{array}$ & 94.6 & 0.0 & 2.4 & 3.0 & 1.8 & 1.1 & 8.6 & 26.9 & 4.0 & 1.5 & 0.5 \\
\hline & $86-96$ & 2.7 & 7.8 & 90.7 & 3.4 & $\begin{array}{c}8 \\
598.0\end{array}$ & 81.4 & 0.0 & 2.1 & 16.5 & 1.9 & 1.2 & 8.2 & 37.0 & 3.9 & 0.3 & 0.5 \\
\hline & & & & & & & & Southe & Baikal & & & & & & & & \\
\hline & & & & & & & Posolsk & cany & -1, hyd & te hill & & & & & & & \\
\hline & $5-15$ & 2.1 & 8.3 & 87.5 & 4.0 & $\begin{array}{c}1 \\
896.3\end{array}$ & 65.5 & 0.3 & 4.4 & 29.8 & 1.7 & 0.6 & 7.1 & 14.7 & 4.2 & 3.1 & 0.4 \\
\hline & $20-30$ & 1.8 & 9.0 & 89.7 & 4.0 & $\begin{array}{c}6 \\
962.4\end{array}$ & 98.0 & 0.0 & 0.2 & 1.8 & 1.2 & 1.0 & 7.6 & 41.7 & 4.0 & 1.5 & 0.3 \\
\hline 12 & $86-96$ & 2.1 & 10.2 & 88.7 & 8.0 & $\begin{array}{c}1 \\
060.5\end{array}$ & 93.1 & 0.0 & 1.3 & 5.5 & 1.3 & 0.8 & 7.8 & 32.4 & 3.9 & 1.8 & 0.3 \\
\hline & $100-110$ & 1.7 & 9.2 & 89.6 & 4.5 & 954.2 & 82.6 & 0.0 & 4.8 & 12.7 & 1.4 & 0.6 & 7.2 & 20.7 & 4.3 & 2.3 & 0.4 \\
\hline & 193-203 & 2.9 & 10.9 & 86.9 & 4.5 & $\begin{array}{c}1 \\
175.7\end{array}$ & 91.4 & 0.0 & 2.1 & 6.5 & 1.6 & 1.1 & 8.2 & 33.0 & 4.2 & 1.2 & 0.3 \\
\hline & & & & & & & & enky, r & ud volc & & & & & & & & \\
\hline & $0-15$ & 1.9 & 15.8 & 80.0 & 1.8 & $\begin{array}{c}3 \\
058.5\end{array}$ & 91.2 & 0.0 & 4.0 & 4.8 & 1.5 & 1.0 & 8.5 & 36.5 & 4.0 & 2.7 & 0.4 \\
\hline 13 & $40-50$ & 2.9 & 11.8 & 83.0 & 8.5 & $\begin{array}{c}3 \\
619.6\end{array}$ & 94.2 & 0.0 & 4.3 & 1.6 & 1.4 & 1.1 & 7.7 & 21.9 & 3.9 & 0.0 & 0.2 \\
\hline & $80-90$ & 3.8 & 23.3 & 72.7 & 2.5 & 292.4 & 14.0 & 0.0 & 0.0 & 86.0 & 0.9 & 1.3 & 3.2 & 7.1 & 1.8 & 0.0 & 0.3 \\
\hline & & & & & & Kedr, $\mathrm{n}$ & mud vol & cano, $\mathrm{g}$ & s hydra & s, carb & onates & & & & & & \\
\hline & $10-20$ & 2.3 & 12.3 & 83.9 & 2.0 & $\begin{array}{c}3 \\
783.0\end{array}$ & 75.6 & 0.4 & 14.9 & 9.1 & 1.1 & 0.8 & 7.1 & 11.2 & 3.7 & 1.5 & 0.7 \\
\hline 14 & $75-85$ & 2.3 & 8.8 & 81.9 & 2.6 & $\begin{array}{c}6 \\
350.8\end{array}$ & 77.5 & 0.0 & 17.0 & 5.4 & 1.9 & 1.0 & 7.8 & 17.5 & 4.4 & 1.5 & 0.6 \\
\hline & $120-135$ & 1.4 & 10.0 & 85.0 & 2.0 & $\begin{array}{c}2 \\
842.9\end{array}$ & 85.8 & 0.0 & 7.1 & 7.1 & 0.5 & 0.9 & 7.5 & 41.0 & 3.4 & 0.5 & 0.6 \\
\hline & $0-10$ & 2.4 & 24.8 & 67.4 & 1.5 & 785.6 & 84.8 & 0.0 & 12.8 & 2.4 & 0.9 & 0.7 & 7.1 & 16.8 & 3.6 & 1.6 & 0.3 \\
\hline & $20-30$ & 1.3 & 12.9 & 78.2 & 2.5 & 271.1 & 82.6 & 0.0 & 12.7 & 4.8 & 0.8 & 0.6 & 9.9 & 11.8 & 4.6 & 1.5 & 0.4 \\
\hline 15 & $45-55$ & 1.7 & 12.1 & 81.3 & 1.6 & 442.5 & 87.7 & 0.0 & 6.7 & 5.5 & 1.1 & 0.8 & 10.8 & 28.7 & 4.6 & 0.0 & 0.3 \\
\hline 15 & 95-105 & 1.4 & 19.2 & 73.1 & 3.0 & 766.5 & 93.1 & 0.0 & 5.6 & 1.3 & 1.1 & 0.8 & 10.1 & 18.4 & 4.1 & 0.0 & 0.3 \\
\hline & $120-130$ & 1.0 & 14.3 & 79.4 & 2.3 & 543.1 & 93.6 & 0.0 & 5.0 & 1.4 & 0.9 & 0.8 & 10.2 & 25.8 & 4.4 & 0.0 & 0.3 \\
\hline & $166-174$ & 1.0 & 16.2 & 76.5 & 2.3 & 579.2 & 94.1 & 0.0 & 4.4 & 1.5 & 0.9 & 0.8 & 9.0 & 22.9 & 3.8 & 0.0 & 0.4 \\
\hline & & & & $\begin{array}{l}1 \beta= \\
\text { ual c } \\
\text { tal co } \\
\text { Alk.- } \\
\text { of grc } \\
\text { immat } \\
7 \text { OEP } \\
\text { OEP27 } \\
{ }^{9} \mathrm{CPI} \\
\text { conten }\end{array}$ & $\begin{array}{l}=(\mathrm{EOI} \\
\text { compon } \\
\text { ontent } \\
\text {-n-alkar } \\
\text { coups o } \\
\text { ture h} \\
\text { ?n }=(\mathrm{n}-\mathrm{C} \\
7-31=( \\
=2^{*}(\mathrm{n}-\mathrm{C} \\
\mathrm{nt} \text { of ret }\end{array}$ & $\begin{array}{l}\text { M1/TOC) } \\
\text { lent-aspl } \\
\text { of molec } \\
\text { nes, Ster. } \\
\text { of } n \text {-alkar } \\
\text { opanes a } \\
\text { Cn- } 2+6 \times \\
\text { OEP27 + } \\
\text { C23 + n-C } \\
\text { ene in tot }\end{array}$ & $\begin{array}{l}\text { r.-stera } \\
\text { ines, st } \\
\text { and ho } \\
\times \text { n-Cn } \\
\text { OEP29 } \\
25+\text { - } \\
\text { tal PAH }\end{array}$ & $\begin{array}{l}\text { narke } \\
\text { nes, } \\
\text { eranes } \\
\text { penes) } \\
+ \text { n-Cn } \\
+ \text { OEP } \\
\text { C27 + }\end{array}$ & $\begin{array}{l}\text { Compc } \\
\text { sum } \\
\text { (MM } \\
\text { rp.-te } \\
\text { (regula } \\
\text { and P } \\
-2) /(4> \\
1) / 3 \text {; } \\
\text { C29)/( } \\
\text { IPI1 = }\end{array}$ & $\begin{array}{l}\text { Kanes, } \\
\text { and } \\
\text { Hs a } \\
\text { n-Cn- } \\
\text { TAR } \\
\text { C22 }\end{array}$ & $\begin{array}{l}\text { of EOM } \\
\text { o); }{ }^{3} \text { A } \\
\text { lative c } \\
\text { PAH- } \\
\text { dia-), te } \\
\text { e listed } \\
+4 \times n- \\
=(n-C 27 \\
2 *(n-C 24 \\
+2 M P)\end{array}$ & $\begin{array}{l}11 \text { fract } \\
\text { Al- alip } \\
\text { content } \\
\text {-polycyc } \\
\text { erpanes } \\
\text { I in Ta } \\
\text {-Cn+1); } \\
+ \text { n-C29 } \\
4+\text { n-C2 }\end{array}$ & $\begin{array}{l}\text { ion }(\mathrm{H} \\
\text { hatic H } \\
\text { (\%) of } \\
\text { lic aror } \\
\text { (tri- a } \\
\text { ble S1. } \\
\text { OEP1 } \\
+\mathrm{n}-\mathrm{C} 3 \\
6+\mathrm{n}-\mathrm{C} 2 \\
\mathrm{MP}+1 \mathrm{M}\end{array}$ & $\begin{array}{l}\text { Cs-oils } \\
\text { Cs, A } \\
\text { the } \mathrm{m} \\
\text { natic } \mathrm{H} \\
\text { ad tetr } \\
6 \mathrm{Pr} \\
7-19= \\
/(\mathrm{n}-\mathrm{C} 1 \\
8)+\mathrm{n}-\mathrm{C} \\
\text { (P) }[81]\end{array}$ & $\begin{array}{l}\mathrm{s}, \text { Res } \\
\mathrm{r} \text {-aro } \\
\text { main g } \\
\text { HCs; a } \\
\text { racyclic } \\
\mathrm{r}-\text { pris } \\
=(\mathrm{OE} \\
15+\mathrm{n}-( \\
\mathrm{C} 30))[8\end{array}$ & $\begin{array}{l}\mathrm{ns} \text { and } \mathrm{t} \\
\text { natic } \mathrm{HC} \\
\text { roups of } \\
\text { ll the cor } \\
\text { mature } \\
\text { ane, Ph- } \\
\mathrm{P} 17+ \\
17+\mathrm{n}-\mathrm{C} 1 \\
1] ; \quad 10\end{array}$ & $\begin{array}{l}\text { the resid- } \\
\text { s; To- } \\
\text { MM: n- } \\
\text { mponents } \\
\text { hopanes, } \\
\text {-phytane; } \\
\text { OEP19)/2; } \\
\text { 19) [80,81]; } \\
\text { Relative }\end{array}$ \\
\hline
\end{tabular}



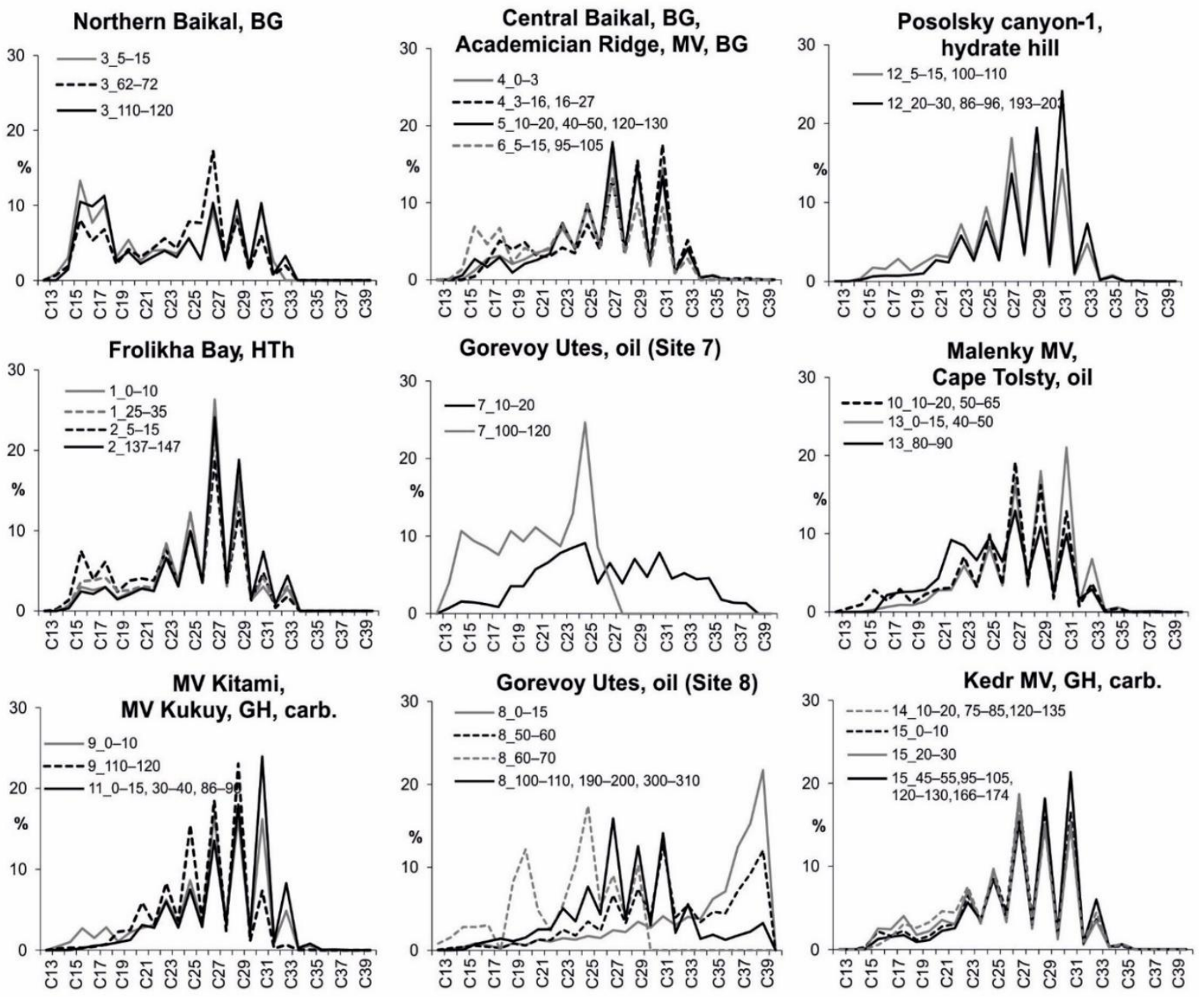

Figure 2. Relative distribution of n-alkanes $n-C_{13}-n-C_{40}(\%)$ in the OM of bottom sediments of Lake Baikal. The most representative lines are selected to display $n$-alkanes distribution in layers of one sediment core with similar chromatographic profiles.

The most prominent maximum of $n-\mathrm{C}_{16}, n-\mathrm{C}_{18}$ homologues is detected in bottom sediments of the northern Baikal and Academician Ridge, and also in the hydrothermal region Frolikha, where the red-ox environmental conditions ( $\mathrm{Pr} / \mathrm{Ph}<1$; Table 2$)$ may promote the reduction of carboxyl groups of fatty acids of the local biota. The predominance of odd-number LMW n-alkanes $n-C_{15}-n-C_{19}$ (OEP17-19 up to 3.4, site 8; Table 2) is detected in some oil-bearing layers of the Gorevoy Utes area, that together with the maximum of $n-\mathrm{C}_{20}$ and $n-\mathrm{C}_{25}$ and the absence of the HMW homologues $n-\mathrm{C}_{26}-n-\mathrm{C}_{38}$ may attest to the active biodegradation. The presence of the unresolved complex mixture (UCM) on the TIC chromatographic profiles of sites $7(10-120 \mathrm{~cm})$ and $8(0-70 \mathrm{~cm}$; Figure 3a) confirms this assumption [82].

The sharp increase of HMW $n$-alkanes content $\left(n-\mathrm{C}_{35}-n-\mathrm{C}_{39}\right)$ in OM of sediments from the Gorevoy Utes (site 8) is a unique phenomenon that requires special attention (Figure 2). Quite possibly, the homologue $n-C_{39}$ peak is just an element in a series of $n-C_{35+}$ n-alkanes, which full length we do not see due to the GC method restrictions. Such distribution is a characteristic of the asphaltene fraction of crude oils [83] but was not found in fresh and biodegraded oils of lake Baikal where the content of HMW homologues $n-\mathrm{C}_{30+}$ sharply decreases [84]. However, the presence of UCM, total absence of isoprenoids, high level of n-alkanes maturity (CPI $\leq 2$; Table 2) and decrease of $n-C_{35}-n-C_{39}$ homologues content with depth in the studied samples (site 8, 0-15, 50-60 cm) may indicate aerobic 
biodegradation processes which lead to the partial loss of lower MW and the preservation of higher MW n-alkanes [85].

Isoprenoid HCs (pristane and phytane) are detected in all samples, except surface sediments of Gorevoy Utes (site 8), and their content reaches maximum values for the region in the deeper layers of site $7(100-120 \mathrm{~cm})$ and $8(60-70 \mathrm{~cm})$. Values of the isoprenoid ratio (Pr/Ph from 0.5 to 3.2; Table 2), which is a traditional indicator of the red-ox environments [81], show significant variations between the studied sites and indicate the changes in conditions of sedimentation from reducing to moderately oxidizing. Herewith, the increased content of pristane may be associated with the additional input of highly mature OM of kerogen [86]. The highly reducing conditions of sedimentation are detected in sediments of hydrothermal vent Frolikha and some layers of sediments from MV Malenky and Kedr, which are likely associated with liquid and gas fluid discharge. The wide range of values demonstrated on the Connan-Cassou diagram (Figure 3b; $[87,88]$ attests to the mixed, predominantly terrigenous origin of the OM in the region. The highest level of OM thermal maturity is detected at the bottom layers of the core from Gorevoy Utes, in sediments from MV Kukuy, Kedr (site 15) and in the upper part of the core from MV Malenky. According to the diagram (Figure 3b), the highest level of biodegradation show sediments from the Academician Ridge (site 5, MV), the lower part of the cores 14 (MV Kedr) and 10 (oil show Cape Tolsty) and the surface sediments of core 4 (the northern Baikal).

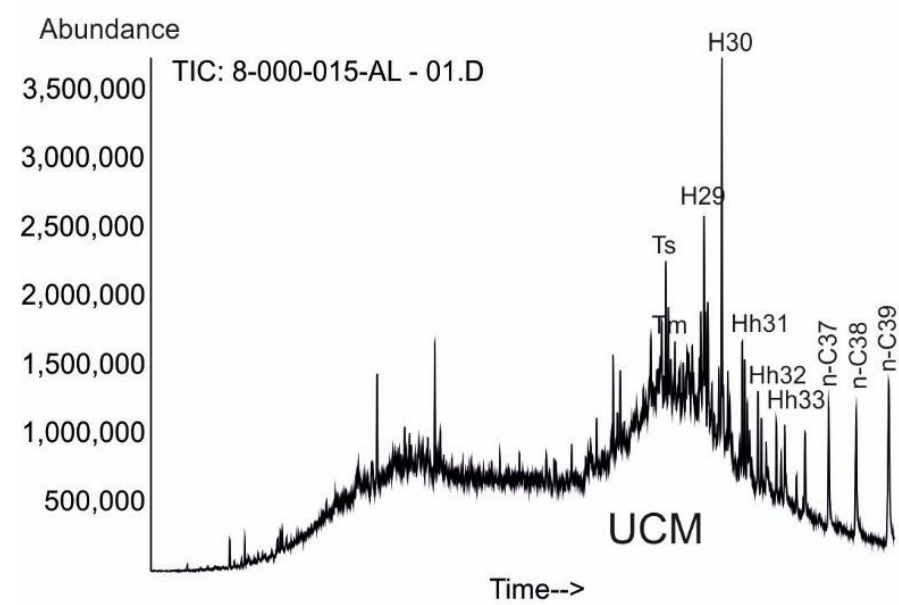

a

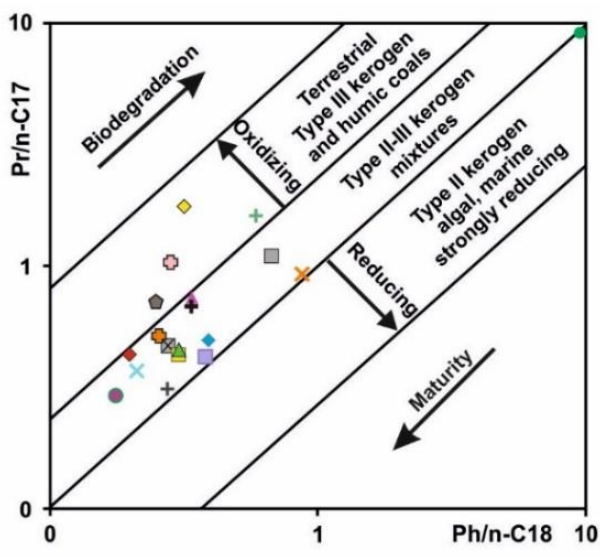

$(1,2)$ Frolikha Bay, HTh (10) Cape Tolsty, oil, 50-65 cm (3) Northern Baikal, BG (11) Kukuy, MV, GH, Carb. (4) Ushkany Islands, BG, 0-3 cm $\Delta$ (12) Posolsky canyon-1, GH, 5-15, 100-203 cm $凶(4)$ Ushkany Islands, BG, 3-27 cm $\Delta$ (12) Posolsky canyon-1, GH, 20-96 cm $\diamond(5)$ Academician Ridge, MV $\quad$ (13) Malenky, MV, 0-50 cm (7) Gorevoy cliff, oilt, 0-110 cm +(14) Kedr, MV, GH, carb., 10-20, 120-135 cm (8) Gorevoy cliff, oil, $110-310 \mathrm{~cm} \quad+(14)$ Kedr, MV, GH, $75-85 \mathrm{~cm}$ (9) Kitami, MV $\quad+$ (15) Kedr, MV, GH, carb.

Figure 3. (a) Total ion chromatogram showing the distribution of aliphatic components in OM of Gorevoy Utes (site 8) surface sediments. Abbreviations of $n$-alkanes and hopanes are defined in Table 1S. (b) A cross-plot of pristane/n-C17 (Pr/n-C17) versus phytane/n-C18 (Ph/n-C18) (modified after [89] shows a difference in facies and OM maturity between the studied sediment cores (averaged values for several layers of one core are shown, see legend). $\left({ }^{*}\right)$ Values are out of the chart area.

Variations in isoprenoid parameters reflect the influence of focus fluid discharge processes on the vertical migration of the ancient material enriched in thermally mature OM to the bottom surface. Moreover, the scatter of data allows detecting layers of sediments from the fluid discharge zones with active biodegradation associated with high biodiversity and favorable environmental conditions [18,90].

\subsubsection{Terpanes and Steranes}

A high concentration of terpanes in which hopanes are the major constituents (Figure 4a) reflects the input of prokaryotic OM [81] and is detected in some layers of Frolikha Bay 
sediments, Gorevoy Utes, Cape Tolsty and MV Kedr (Table 2). The molecular composition of terpanes is one of the most interesting characteristics of OM of Lake Baikal because it reflects the unique biodiversity and development of the microbial communities in the sediments of the lake.

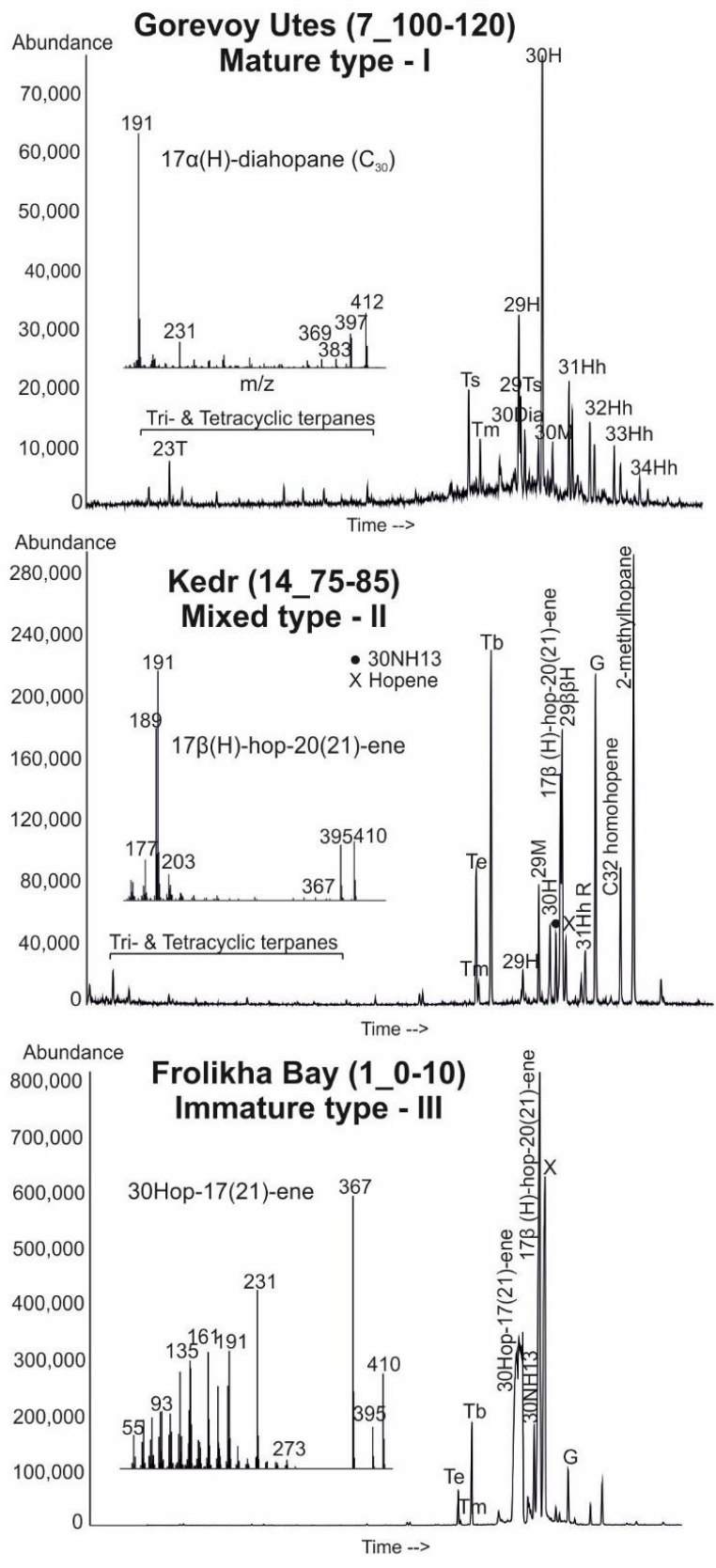

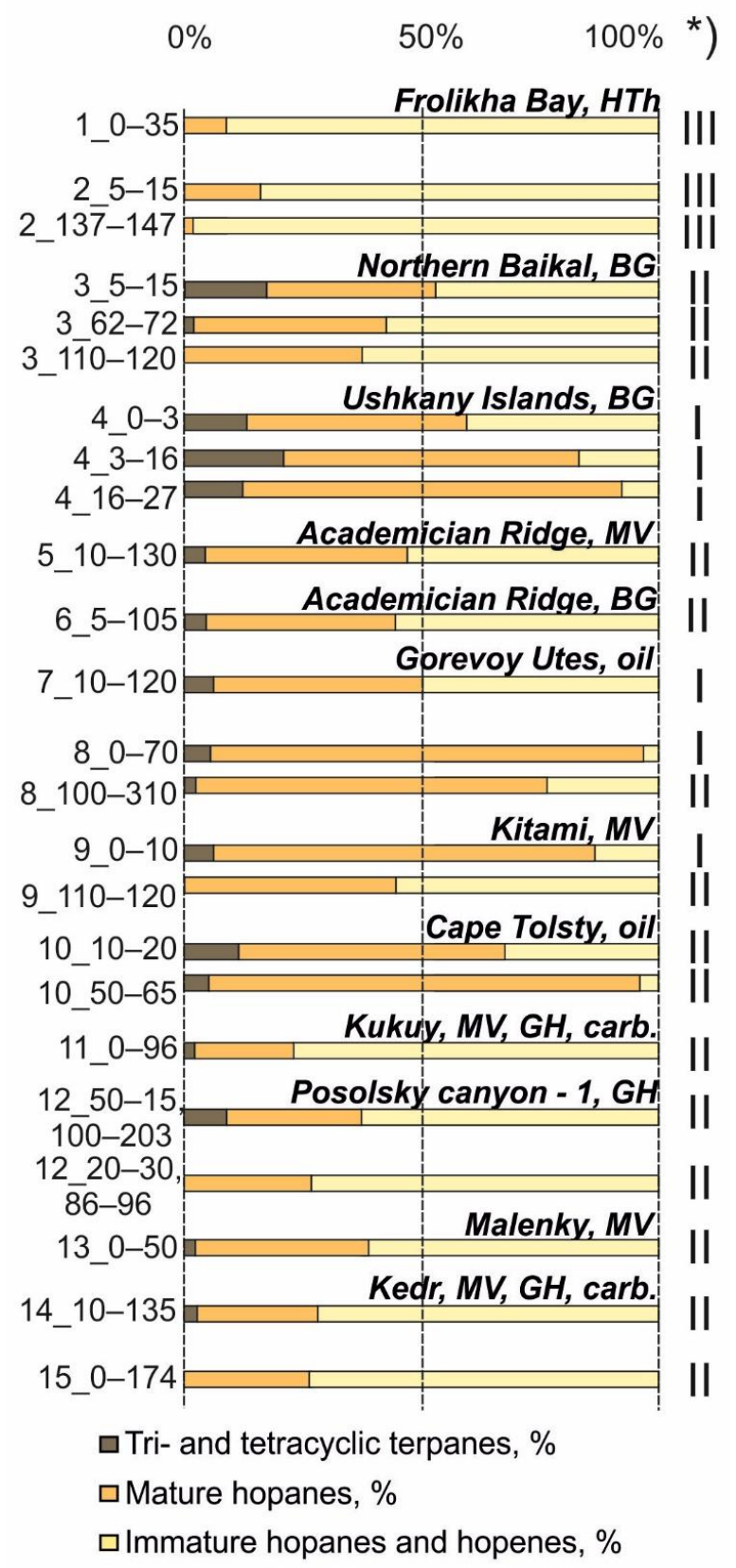

$\mathrm{b}$

Figure 4. (a) Examples of the three main types of terpanes distribution (chromatogram of $m / z 191$ for the most representative samples): mature (I), mixed (II) and immature (III). Mass spectra of the most rare and specific hopane components are shown here in the insets and in Figure 5. All abbreviations are defined in Table S1. (b) Group characteristics of terpanes of all the sites (total terpanes normalized values of tri- and tetracyclic terpanes, mature and immature hopanes, in \%). Components of each group are listed in Table S1. The averaged values for several layers of one core are shown (see Y-axis labels). *) The number of chromatogram type - I, II or III (Figure 4a) is indicated in the left vertical column. 
The "mature" type of terpanes distribution (number I, Figure 4a) is the most frequent characteristic of OM of the pelagic sediments of different marine and freshwater basins but is detected only in sediments from oil shows Gorevoy Utes $($ site 7,8$)$ and Cape Tolsty (site 10). The low content of immature hopanes in the OM of sediments from the northern Baikal (site 4) and in the surface clay of MV Kitami (site 9), which sediment section contain a gas hydrate, allows to attribute them to the mature type too. The main characteristics of the molecular composition of the mature type of Lake Baikal terpanes include stable forms of trisnorhopanes - Ts and Tm (Ts/(Ts+Tm) $\geq 4$; Figures $4 \mathrm{a}$ and $6 \mathrm{a})$, the series of H29-H35 $\alpha \beta$-hopanes with high values of homohopanes ratio H31 S/(S+R) $\geq 0.4$ (Figures $4 \mathrm{a}$ and 6a), significant content of C30 moretane (stable $\beta \alpha$ geohopane) and C30 diahopane, which forms during the oxidative catalytic transformation of hopenes in a clayey environment [81]; Figure $4 \mathrm{a}$, inset). The gradual increase of mature hopane components deep in the sediments of the northern Baikal basin (site 4) is likely associated with the low sedimentation rate and local diagenetic processes. This agrees with the highest content of tri- and tetracyclic terpanes ( $\mathrm{Tt} 23 / \mathrm{H} 30$ up to 0.4 ) - the structures stable to biodegradation that originate from freshwater or marine algae and land plant sources [91]. The surface layer of the core from MV Kitami (site 9) does not contain diatomaceous silt and is represented by clay deposits likely due to the uplift migration or redeposition of the ancient material enriched in OM of post-diagenetic maturity level. Thus, the "mature" type of terpane distribution in the surface layer of the core is consistent with this assumption.
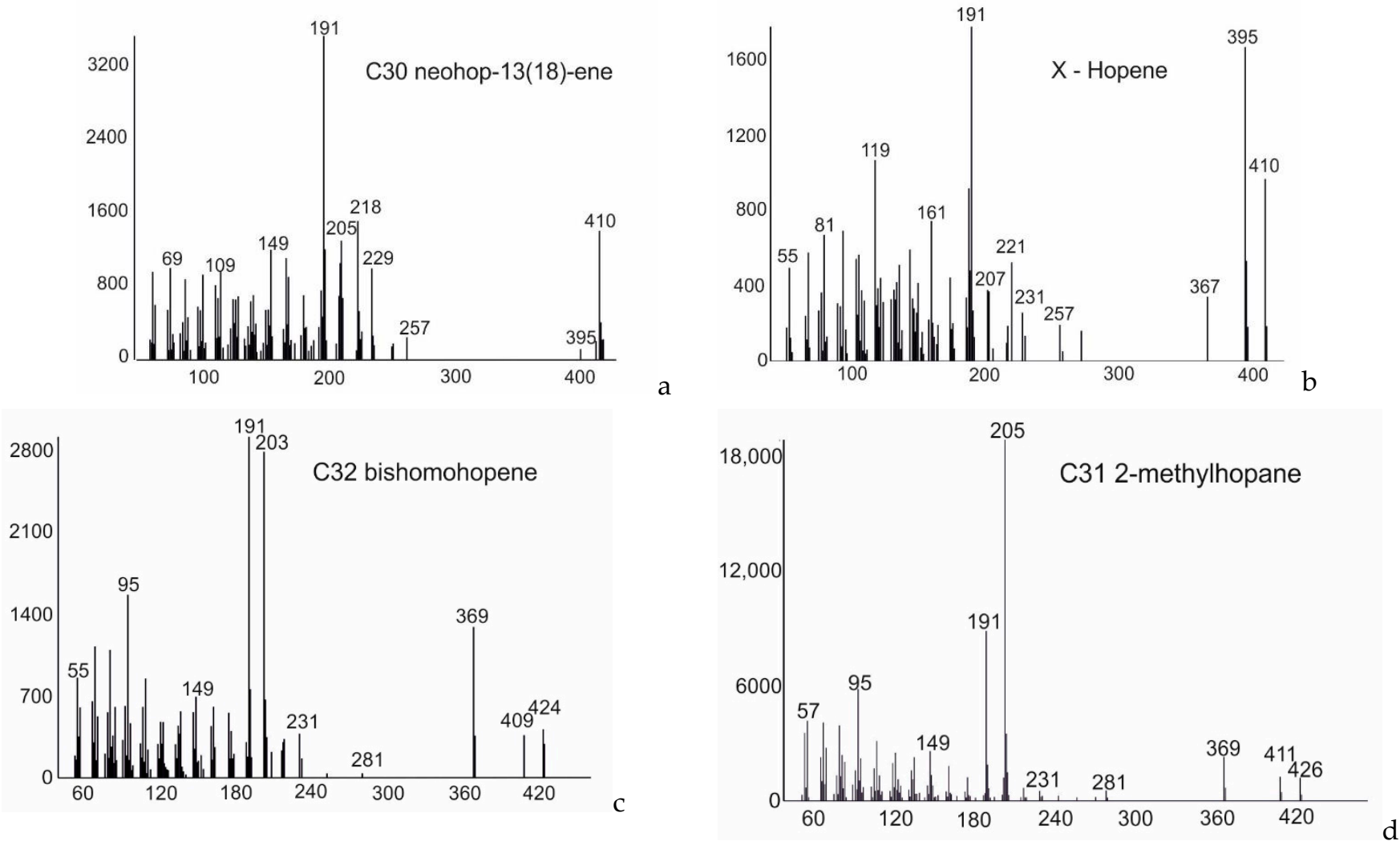

Figure 5. Mass spectra of hopane structures $(\mathrm{m} / \mathrm{z}$ 191) characteristic of the mixed and immature type of terpane profiles of Lake Baikal sediments: (a)—C30 neohop-13(18)-ene; (b)—X, Hopene with the unknown structure; (c)—C32 bishomohopene; (d)—C31 2-methylhopane. 


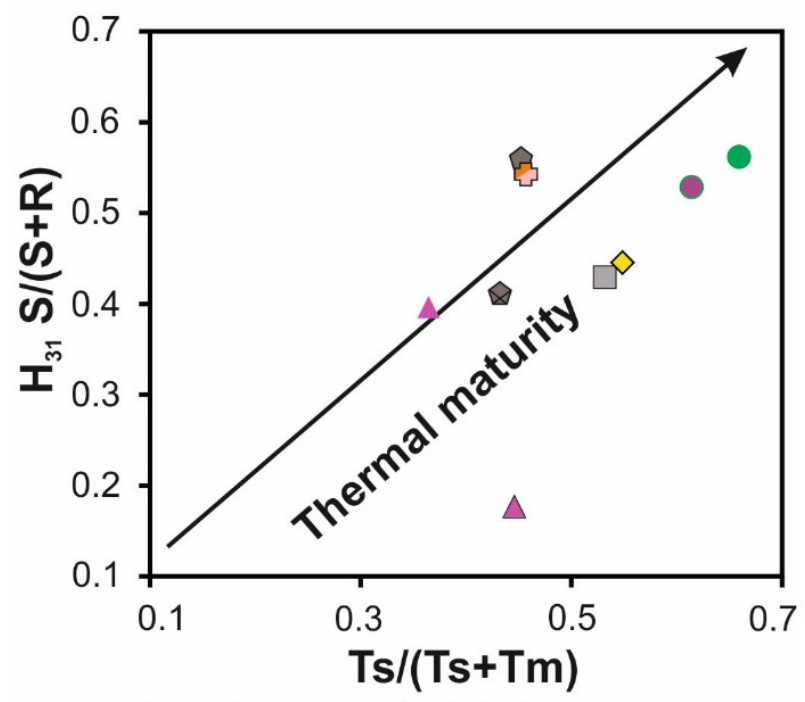

(4) Ushkany Islands, BG, 0-27 cm

$\diamond(5)$ Academician Ridge, MV, $10-130 \mathrm{~cm}$

(7) Gorevoy Utes, oil, 10-20, 100-120 cm

(8) Gorevoy Utes, oil, 0-310 cm

(9) Kitami, MV, 0-10 cm

(9) Kitami, MV, 110-120 cm

(10) Cape Tolsty, oil, 10-20, 50-65 cm

(12) Posolsky canyon-1, GH, 5-15 cm

$\Delta$ (12) Posolsky canyon-1, GH, 193-203 cm

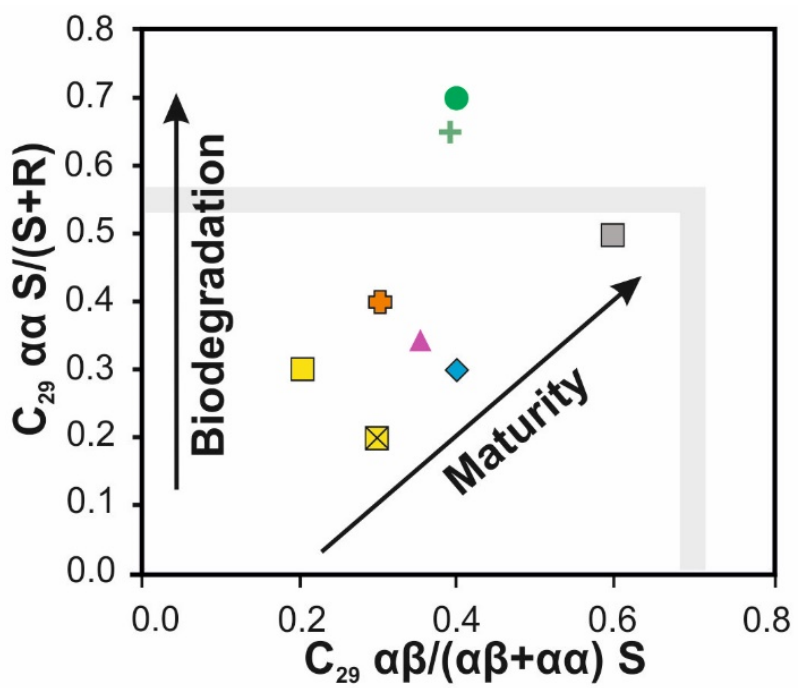

(3) Northern Baikal, BG, 5-15 cm

$\square$ (4) Ushkany Islands, BG, 3-16 cm

$\otimes(6)$ Academician Ridge, BG, 5-15 cm

$\square$ (6) Academician Ridge, BG, 95-105 cm

(7) Gorevoy Utes, oil, 10-20, 100-120 cm

ら(10) Cape Tolsty, oil, 10-20 cm

$\Delta$ (12) Posolsky canyon-1, GH, 5-15 cm

+(14) Kedr, MV, GH, 10-20 cm

Figure 6. Cross plots of thermal maturity parameters based on: (a) trisnorhopanes (Ts and Tm) and H31 homohopanes distribution ( $m / z$ 191); (b) isomerisation at asymmetric centers of C29 steranes $(m / z$ 217). The averaged values for several layers of one core are shown (see legend). Maturity trend lines are adapted from [81]; all abbreviations are listed in Table S1.

Terpane profiles of most Baikal sediments are represented by the less mature forms that, for convenience, are marked here as mixed (II) and immature (III) types of distribution (Figure 4a). The predominance of immature $\beta \beta$-hopanes and hopenes in the mixed type of distribution is accompanied, however, by the input of mature constituents. This may be due to the inflow of clay particles with terrigenous runoff, erosion and redeposition of ancient sediments and an uplift of the mud breccia to the bottom surface. The mixed type is characteristic for most Lake Baikal sediments and it does not show significant variations in components, only in their ratios (Figure 7). In contrast to the mature type, in the mixed type, the less stable structures-22,29,30-trisnorhop-17(21)-ene (Te) and $17 \beta(\mathrm{H})-22,29,30$-trisnorhopane $(\mathrm{Tb})$ predominate in the composition of trisnorhopanes. The content of mature components (H29-H31 $\alpha \beta$, moretane C29 $\beta \alpha$ and gammacerane) is significantly lower than the less stable structures-C29 $\beta \beta$ hopane, $17 \beta(\mathrm{H})$-hop-20(21)-ene, C30 neohop-13(18)-ene, C32 homohopene, 2-methyl-17 $\alpha(\mathrm{H}), 21 \beta(\mathrm{H})$-hopane and hopene, with an unidentified structure (X; Figures $4 \mathrm{a}$ and $5 \mathrm{~b})$. 


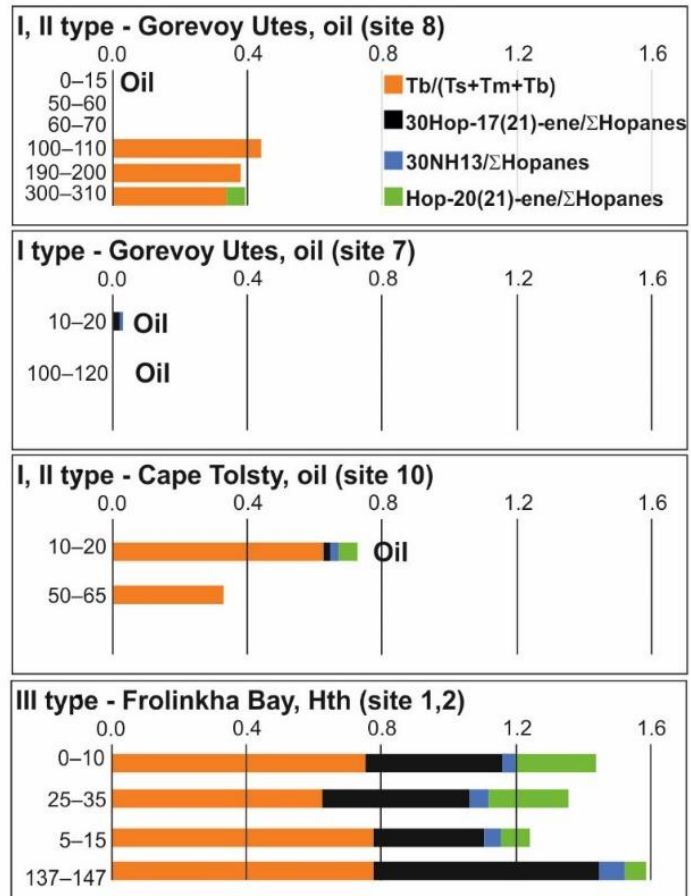

Il type - Northern Baikal, BG (site 3)
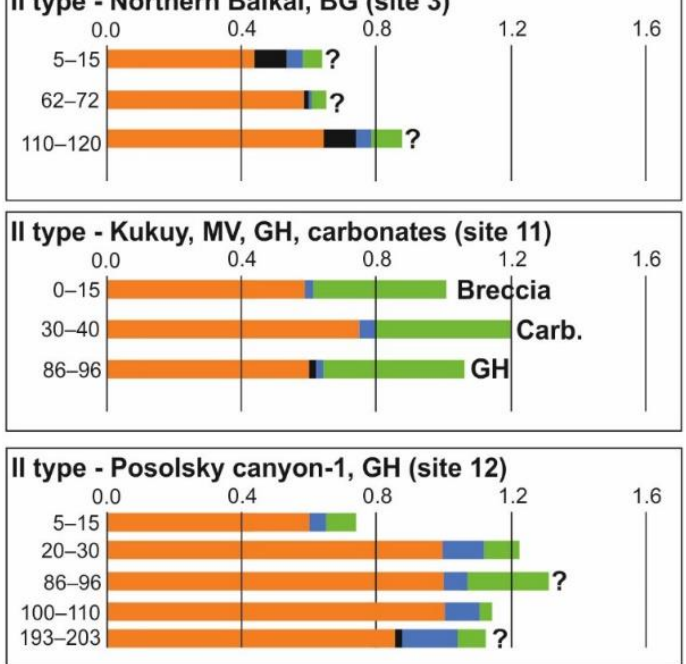

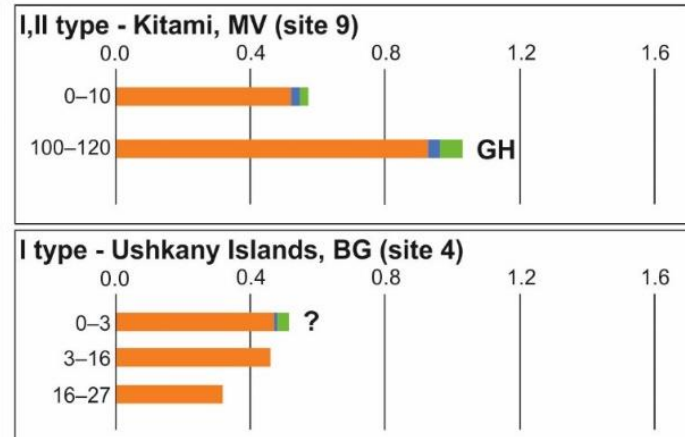

II type - Academician Ridge, MV (site 5)

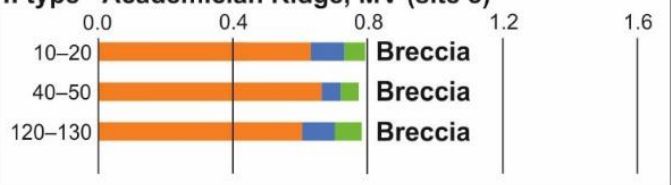

II type - Malenky, MV (site 13)
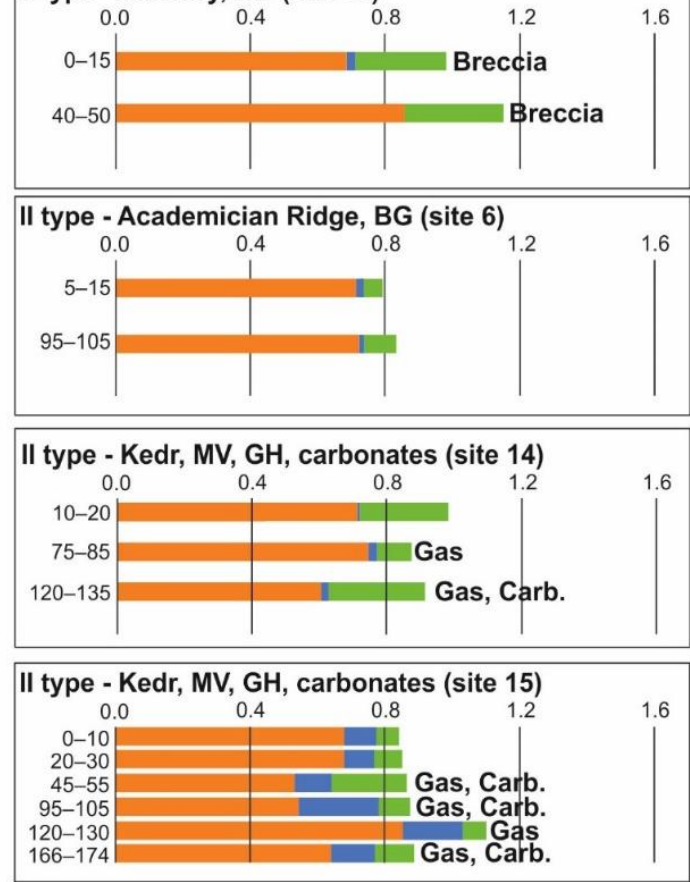

Figure 7. Input of immature hopanes to the OM of sediments of Lake Baikal. The vertical rows of data are arranged according to the studied core intervals. Individual hopenes are normalized to the total content of hopanes ( $\sum$ Hopanes $=\sum$ mature, mixed, immature hopanes, all compounds are listed in Table S1). The intervals with focused fluid discharge are marked as oil—oil channel; HTh-hydrothermal vent; GH—gas hydrate; Breccia—mud volcanic breccia; Gas-gas-bearing layer; Carb-authigenic carbonates; ?-no detected fluid discharge, but the data attest to the growth of microbial activity. I, II, III-type of terpanes distribution according to Figure 4a.

Most of these structures are specific markers of prokaryotic OM of the early diagenetic stage of transformation. For example, such rare structures as hop-20(21)-enes (Figure 4a, the inset), whose precise origin is still incompletely understood, may be generated by catalytic oxidation of the less stable bacterial marker-diploptene (hop-22(29)-ene) in the clayey environment $[60,92]$. The stronger oxidation leads to the formation of neo-13(18)-ene from diploptene (Figures $4 \mathrm{a}$ and 5a; [93]). Both products are detected in immature coals and source rocks and are characteristic of the OM of most sediments of Lake Baikal, except areas with oil discharge (Gorevoy Utes and Cape Tolsty) and the lower part of the section of the northern basin (site 4). Variations in their relative content attest to the different 
stages of diploptene transformation likely associated with the presence of a clay catalyst. The maximum values are detected in zones with mud volcanic activity and in layers that contain mud breccia, gas or liquid fluid (HTh vent Frolikha; MV Academician Ridge; MV Kukui; MV Malenky; MV Kedr; Figure 7). This agrees with their formation during microbial generation and biodegradation of OM. Other immature structures detected in most sediments of the lake are C30 hopene with an unidentified structure (Figures $4 \mathrm{a}$ and $5 \mathrm{~b}$ ) and two intensive peaks located between H32 and H33 homohopanes on the chromatogram ( $m / z$ 191), identified as C32 homohopene and 2-methylhopane (Figure 5c,d; [59,61]).

Parfenova et al. [61] have described the molecular structure of homohopene detected in the organic-rich limestones of the Sinyaya Formation (Lower Cambrian) and its homologues series was found in the mid-Cretaceous silty sandstones and mudstones of Hokkaido [94]. The nature of these compounds is still incompletely understood, but there is an assumption about their origin from bacteriohopanepolyol, which is a component of bacteria living in water, soil and sediments [95]. It is important to note that the revealed homologue of homohopene comes later on the chromatogram $(\mathrm{m} / \mathrm{z} 191)$ than the described C31 compound [61], and most likely has 32 carbon atoms. According to the scheme suggested in [95], the C32 homologue is one of the most stable forms of homohopenes that can be found in the OM of the diagenetic level of transformation.

There is much more information about the structure and distribution of 2-methylhopanes for today. Thus, their main precursors, 2-methylhopanepolyols, are widespread in the ancient deposits, modern microbial mats and bacterial cultures [59,96-98]. It was shown that these compounds are genetically associated with cyanobacteria and/or methylotrophs [59]. Herewith, cells of cyanobacteria often generate more stable C32 2-methylhopanes, while in sediments of Lake Baikal, only C31 homologue was detected (Figures 4a and 6d). Moreover, all sediments with a mixed and immature type of terpane distribution contain gammaceran that is traditionally considered a product of tetrahymanol, a component of marine and freshwater sediments, photosynthetic sulfur bacteria and ferns, which occurs in stratified oxygen-poor water environments $[99,100]$. However, the experimental study of gammaceran formation in conditions characteristic for the $\mathrm{HCs}$ generation zone $\left(80^{\circ} \mathrm{C}, 5 \mathrm{mpa}\right)$ has revealed another possible source for this compound in the sediments of Lake Baikal. It was shown that the enrichment of sediments with the biomass of Baikal diatom Ulnaria acus (Synedra acus) leads to the OM composition changes and gammacerane formation in initially clean samples [54]. Received data agree with the result of [101] that has shown gammacerane formation from protozoa biomass feeding on cyanobacteria and microorganisms in various paleoenvironments. Moreover, gammacerane is the main biomarker of lacustrine oils and bitumen, including the "Green River" petroleum deposit in China, where the main sources of OM are algal detritus and bacteria [81].

The last immature type of terpane distribution (III; Figure 4a) was detected only in the Frolikha Bay sediments. The main characteristic of this type of profile is the total absence of tri- and tetracyclic terpanes and mature hopanes and a high content of immature constituents such as Tb, hop-17(21)-ene, hop20(21)-ene and neo-13(18)-ene, which testifies to the intensive input of microbial OM to the sediments (Figures $4 a, b$ and 7). Previous studies [31,102] have shown that the anomaly increase of the content of the other diploptene transformation product C30 hop-17(21)-ene in mud breccia of MV Kedr may be due to the development of chemoorganotrophic microorganisms, which use metabolic products of methanotrophic and, possibly, methanogenic bacteria [103]. Despite the unexpected absence of C30 hop-17(21)-ene in sediments of sites 14 and 15 (MV Kedr), in this study, the low concentration of this compound was detected in surface sediments of oil discharge zones (Gorevoy Utes and Cape Tolsty, site 7, 10) in the bottom layer of the core from southern Baikal (Posolsky canyon-1, site 12) and in gas hydrate-bearing sediments (Kukuy, site 11; Figure 7). The unexpected appearance of the hop-17(21)-ene structure in the sediment core from the background region of northern Baikal (site 3) likely attests to the unrevealed processes of fluid discharge. All these data confirm the assumption about the link between the content of hop-17(21)-ene in the OM of sediments and the microbial 
activity in zones of focus' fluid discharge and also may indicate such processes in zones where they were not detected previously.

Steranes are minor components of the OM of Lake Baikal's bottom sediments (Table 2) and are represented predominantly by ethylcholestanes $\left(C_{29}\right)$ that indicate the input of OM from land plant sources likely associated with clay minerals. It is important to note that the presence of low mature terrigenous components of n-alkanes $\left(\mathrm{OEP}_{27-31} \geq 5\right.$ for most samples; Table 2) and the total absence of steranes in some layers of sediments likely attests to the level of OM transformation insufficient for their generation that agrees with the previous results [31]. Sediments with a significant content of $C_{29}$ steranes (Figure $6 b$ ) differ by level of OM thermal maturity and biotransformation. Thus, the most thermally mature steranes were detected in the OM of background sediments of central Baikal (site 4; Figure $6 \mathrm{~b}$ ), and the most biodegraded OM of eukaryotic genesis was found in Gorevoy Utes sediment core (site 7) and in the surface of MV Kedr (site 14).

\subsubsection{Polycyclic Aromatic Hydrocarbons}

The contribution of PAHs (all compounds are listed in Table S1) to the composition of molecular markers of OM varies from 1.3 to $86 \%$ and the maximum values are detected in sediments from Academician Ridge MV, Gorevoy Utes and MV Malenky (sites 5, 7 and 13 correspondingly). Phenanthrene and its $\mathrm{C} 1-\mathrm{C} 4$ alkyl homologues, cadalene, retene and perylene are the main constituents of PAHs of most Lake Baikal sediments and only samples from oil discharge zones show minimum values of perylene. The input of these compounds attests to the mixed biogenic-petrogenic origin of OM. Thus, cadalene and retene are derivatives of sesqui- and diterpenoids produced by higher plants $[62,104]$. The formation of perylene is usually associated with the transformation of terrigenous and/or marine OM during microbial processes in reducing environments, or the release of water fungi products during the destruction of wood [105-107]. Previous studies have shown that phenanthrene structures may be associated with diterpene transformation [108] or may form by the dehydrogenation of sterols [109]. The ratio of diterpenoid diagenetic products, methylphenanthrenes (MPI1; Table 2; [110]), is based on different thermodynamic stability and bioavailability of the main four isomers (3MP, 2MP, 9/4MP, 1MP). The values of MPI1 reflect the level of OM transformation [81] and point to the wide scatter of its thermal maturity in samples of Lake Baikal—from immature diagenetic (site 1, 137-147 cm) to the late oil catagenetic stage (site 7, 10-120 cm) with a predominance of early and peak oil generation stages in most of the studied samples. However, the strong association of phenanthrene structures with the mineral matrix of terrigenous rocks should be considered.

The distribution and origin of retene in the sediments of Lake Baikal is an important issue that requires special attention. An experimental study has shown that the destruction of algal biomass accompanied by the development of microbial communities in the area of methane seepage may lead to retene formation $[54,90,111]$. However, in this study, the increased content of retene (up to $2 \%$ of total PAHs; Table 2) is detected in sediments of background zones of the lake (site 3, 4,6) and only in some layers of cores from fluid discharge zones (site $8,12,13$ ). High retene concentration in sediments of the background zones may be due to several reasons. The first is input with terrigenous clay minerals, and the second and the most probable is the destruction of diatom Ulnaria acus (Synedra acus) in the surface layer of sediments. This diatom is one of the dominant phytoplankton species, which produces the bulk of primary production of the lake [112]. Despite the fact that retene is conventionally considered a marker of coniferous plants [104], it is often absent in terrestrial petroleum and may be found in sediments and bitumen enriched in algal OM. The previous data on retene generation from algae with the assistance of microorganisms $[113,114]$ agree with the recent experimental result on diatomic biomass destruction by the local microbial community of Lake Baikal [54]. The typical mesophilic bacteria of genus Arthrobacter and Solirubrobacter belonging to the phylum Actinobacteria, and genus Sphingomonas represented by the class $\alpha$-Proteobacteria were dominant in thermobaric conditions of the experiment. The specified taxa have flexible metabolism, which 
helps them to function not only in mesophilic conditions but also adapt to the temperature increase during burial and fluid circulation [115]. The destruction of OM and associated retene formation in the bottom sediments of Lake Baikal may be due to the functioning of the dominant taxa Chloroflexi, Ca. Atribacteria (OP9), Deinococcus-Thermus, Acidobacteria, $\mathrm{Ca}$. Aminicenantes (OP9), Ca. Latescibacteria, Ca. Saccharibacteria, Planctomycetes and Firmicutes [54]. The third reason for the increase of retene concentration in the background regions of Baikal is aerosol transport of combustion products after the extensive wildfires around the lake's coasts. The eolian input of retene to the northern part of the lake from northern Siberia is up to $0.33 \mathrm{ng} / \mathrm{m}^{3}$ and is determined predominantly by the combustion of Pinus sylvestris and Larix sibirica, constituting $80 \%$ of the forest [116].

\subsubsection{Dimethylalkanes}

Besides the traditional set of molecular markers, a series of methylated alkanes (3,5-, 3,6-, 3,7-dimethylalkanes - DMA, m/z 99, 113, 127; Figure 8) were also identified in bottom sediments of Lake Baikal. These structures have been previously detected in OM of recent and partially lithified deposits of Siberia and the Russian Platform $[63,117,118]$ and in sediments of the Academician Ridge of Lake Baikal [111]. Precursors of these compounds with a high probability are di- and tetraether lipids of archaea and bacteria $[63,119]$.

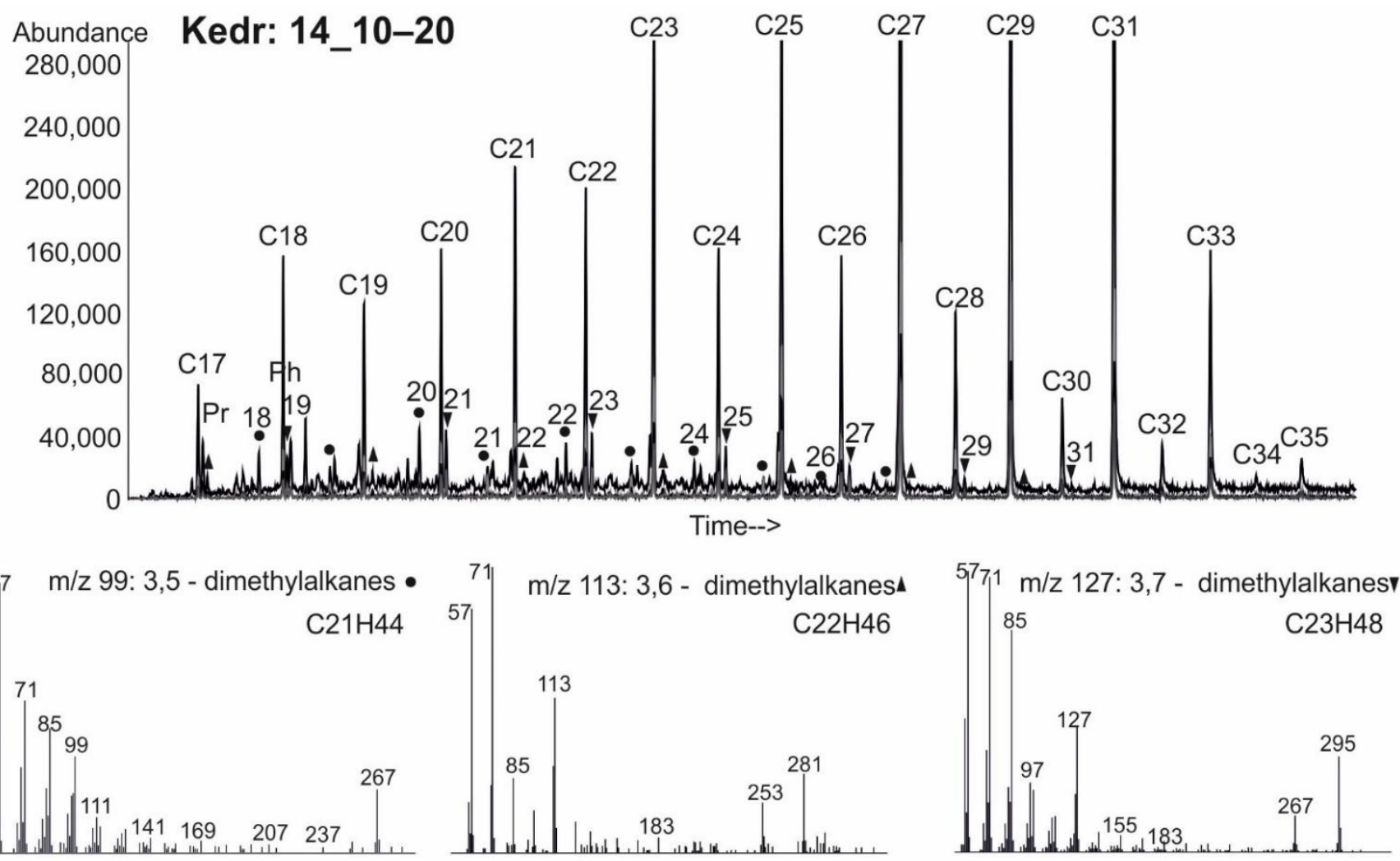

Figure 8. Example of summary mass chromatogram of n-alkanes and 3,5-, 3,6-, 3,7-dimethylalkanes ( $m / z$ 71, 99, 113 and 127 correspondingly) in bottom sediments of MV Kedr (upper line) and mass spectra of DMAs according to their characteristic ions (bottom line).

The received data on the distribution of 3,6-DMA (only even homologues) and 3,7DMA (only odd homologues) agree with the previous research [63], but the series of 3,5-DMA in the OM of bottom sediments of Lake Baikal contains both odd and evenchained homologues that were not detected previously. The ubiquitous distribution of these compounds in the sediments of the lake (even their low content) allows us to define them as a background geochemical characteristic. However, their total absence in the OM of some sediment cores collected from the fluid discharge zone (site 7, 10-120 cm; 8, 0-70 cm; 
9, 110-120 cm; 13, 80-90 cm; 12, 193-203 cm) is also informative and has the potential to be a tool for the anomaly detection.

\subsection{Specificity of OM in Zones of Authigenic Carbonates Formation}

The study of OM and hydrocarbon molecular proxies in sediment cores with layers containing authigenic carbonates (Kukuy, site 11; Kedr, site 14,15) gives a new way to understand the conditions of their formation in the specific environment of Lake Baikal. According to the present conception $[9,49,51,120,121]$, the formation of authigenic carbonates of Lake Baikal is associated with microbial methane generation processes. Acetoclastic methanogenesis is one of the most probable processes of methane formation in anaerobic conditions of freshwater reservoirs, but it shows less evidence in Lake Baikal sediments than the hydrogenotrophic way. Thus, acetate-ion was not detected in the pore water of sediment cores from MV Malenky (up to $139 \mathrm{~cm}$ ) and Kedr (152 cm; [49]). The isotopic composition of siderites from zones of the focus fluid discharge [120] points to their enrichment in ${ }^{13} \mathrm{C}$ compared to methane and ethane. This allows us to consider the microbially transformed $\mathrm{OM}$ of bottom sediments as the initial source of $\mathrm{HCO}^{-}$. Herewith, it is important to note that processes of methane generation, anaerobic methane oxidation (AOM) and authigenic carbonates formation are spatially separated in the sediment section, which complicates the search of their common molecular proxies. The received results on the group and molecular composition of the dispersed OM in bottom sediments with authigenic carbonates and gas hydrates inclusions (MV Kukuy, site 11; MV Kedr, site 14, 15) allows us to emphasize the following:

1. The increased content of EOM2 (ethanol-benzene extract; EOM1/EOM2 < 0.4) is detected in layers of sediments from MV Kukuy and Kedr (11, 0-15 cm; 15, 20-55 cm, $120-174 \mathrm{c} \mathrm{m})$. The same or higher contents are characteristic of MV Malenky $(13,40-50 \mathrm{~cm})$, where carbonate inclusions were also found [9,120], MV from the region of Academician Ridge $(5,40-50 \mathrm{~cm})$ and in two upper layers of the background core with Fe-Mn crusts from northern Baikal $(4,0-16 \mathrm{~cm})$. The use of ethanol-benzene instead of a chloroform solvent allows us to extract more polar components of OM, which contain alcohol, ester and acid groups including fatty acids, resinous substances, terpenoids, waxes, polyphenols and carbohydrates, etc. [122,123] Thus, the increased content of oxidized components in sediments of these areas point to the lower level of OM maturity [124,125].

2. A significant content of humic acids (up to 60\%) is detected in most of the sediments of Lake Baikal. Previous studies [126-128] have shown that degradation of OM with a high content of HAs may lead to the increase of molecular $\mathrm{H}_{2}$ rather than acetate in the anoxic sedimentary environment and a corresponding shift to the hydrogenotrophic methanogenesis instead of the acetoclastic way. This is consistent with the results of radioisotope research and cultivation $[48,126,129]$. Vertical migration of clay deposits with the mud volcanic breccia in sediment cores from MV of the Academician Ridge (site 5), MV Kitami (site 9) and MV Malenky (site 13) determines the growth of HAs concentration with depth and is accompanied by the absence of acetate-ion. However, sediment cores enriched in authigenic carbonates and gas hydrates from the MV Kukuy and Kedr show a significant decrease of HAs content with depth, herewith the acetate concentration is still under the detection limits in these layers $(0.1 \mathrm{mg} / \mathrm{L})$. Thus, we can make a preliminary conclusion that humification is probably not the unique reason for acetate decrease in sediments of the deep-water zone of Lake Baikal.

3. The high content of immature molecular markers of prokaryotic origin (hopanes and hopenes) in the OM of sediment cores from MV Kedr and Kukuy (Figure 4a) is consistent only with the values detected in the sedimentary OM of hydrothermal vent site Frolikha (site 1,2) and may testify to the high microbial activity in the sediment section [129]. Herewith, the increase of content and diversity of immature hopane structures with depth confirms the assumption of the existence of a larger methane generation zone in these regions. 


\section{Conclusions}

The study of a wide set of organic-geochemical proxies in bottom sediments collected from all the geographic zones of Lake Baikal (northern, central and southern basins, Academician Ridge) allowed us to reveal the most effective molecular indicators of hydrocarbon migration in areas of the focused fluid discharge. The complex analysis of hydrocarbon molecular markers distribution (n-alkanes, dimethylalkanes, isoprenoids, tri- and tetracyclic terpanes, hopanes, steranes and PAHs) has shown that the general characteristics of the OM of sediments indicate the predominant input from terrigenous (allochthonous) and algal/microbial (authochthonous) sources and the unique composition of molecular proxies. Herewith, the composition of HC molecular markers in bottom sediments of the focus fluid discharge zones (liquid and gas seepage, oil shows, hydrothermal venting, mud volcanism and associated gas hydrates and authigenic carbonates) varies significantly due to the environmental conditions and local microbial activity. Thus, the specific immature hopane structures are identified in sediments of sites with the detected vertical migration of the mud breccia to the bottom surface due to microbial activity (MV Kukuy, Kitami, Malenky, Kedr). The increased content of microbial OM is associated with gas-bearing intervals of these cores, which also contain gas hydrates and authigenic carbonates. The maximum of microbially degraded $\mathrm{OM}$ in deposits from the regions with oil discharge is registered both at the top (Cape Tolsty) and at the bottom (Gorevoy Utes) of sediment sections and points to the development of different archaea and bacterial communities. The unique distribution of immature hopane structures defined in bottom sediments of the hydrothermal vent site Frolikha attests to the active development of chemoorganotrophic microorganisms that most likely use methane as the main carbon source. The analysis of $\mathrm{OM}$ in sediment layers enriched in authigenic carbonates and gas hydrates point to the specificity of its group and molecular characteristics (the growth of polar lipids fraction content, changes in HAs distribution through the core, specific immature hopane profiles), but the significant increase of knowledge in this field is still required to make more reliable conclusions. It is interesting to note that different molecular signs of microbial activity were registered in the OM of sediment cores without any signs of fluid discharge (northern Baikal background) and with high probability indicate the presence of undetected anomalies in these regions.

Supplementary Materials: The following supporting information can be downloaded at: https: / / www.mdpi.com/article/10.3390/geosciences12020072/s1, Table S1: list of compounds (molecular ions) and their abbreviation.

Author Contributions: Conceptualization, I.M., Krylov A. and P.S.; methodology, I.M.; software, I.L.; validation, P.S., S.B., O.P. and T.Z.; formal analysis, A.K.; investigation, I.M.; resources, S.M., T.Z.; data curation, O.K.; writing — original draft preparation, I.M.; writing—review and editing, Krylov A., P.S., O.P., S.B., T.Z., O.K.; visualization, A.K., I.L.; supervision, Krylov A.; project administration, A.A.K., P.S., S.M.; funding acquisition, A.A.K., T.Z. All authors have read and agreed to the published version of the manuscript.

Funding: This research was funded by Russian Scientific Foundation grant number 19-17-00226; The expeditions were funded by state assignment number 0279-2021-0006 (121032300223-1).

Data Availability Statement: All data used during the study appear in the submitted article.

Acknowledgments: We are grateful to the crew of the R/V G.Yu. Vereshchagin for their assistance in expeditionary work.

Conflicts of Interest: The authors declare no conflict of interest. The funders had no role in the design of the study; in the collection, analyses, or interpretation of data; in the writing of the manuscript, or in the decision to publish the results. 


\section{References}

1. Kuz'min, M.I.; Karabanov, E.B.; Kawai, T.; Williams, D.; Bychinskii, V.A.; Kerber, E.V.; Kravchinskii, V.A.; Bezrukova, E.V.; Prokopenko, A.A.; Geletii, V.F.; et al. Deep drilling on Lake Baikal: Main results. Russ. Geol. Geophys. 2001, 42, 8-34.

2. Granin, N.G.; Makarov, M.M.; Kucher, K.M.; Gnatovsky, R.Y. Gas seeps in Lake Baikal-Detection, distribution, and implications for water column mixing. Geo-Mar. Lett. 2010, 30, 399-409. [CrossRef]

3. Khlystov, O.; De Batist, M.; Shoji, H.; Hachikubo, A.; Nishio, S.; Naudts, L.; Poort, J.; Khabuev, A.; Belousov, O.; Manakov, A.; et al. Gas hydrate of Lake Baikal: Discovery and varieties. J. Asian Earth Sci. 2013, 62, 162-166. [CrossRef]

4. Mats, V.D.; Efimova, I.M. Geologic history of Lake Baikal. Priroda 2017, 3, 13-27. (In Russian)

5. Garkusha, D.N.; Fedorov, Y.A.; Tambieva, N.S.; Andreev, Y.A.; Mikhaylenko, O.A. Methane in water and bottom sediments of Lake Baikal. Water Resour. 2019, 46, 511-522. [CrossRef]

6. $\quad$ Klerkx, J.; Zemskaya, T.I.; Matveeva, T.V.; Khlystov, O.M.; Namsaraev, B.B.; Dagurova, O.P.; Golobokova, L.P.; Vorobyova, S.S.; Pogodaeva, T.P.; Granin, N.G.; et al. Methane hydrates in surface layer of deepwater sediments of Lake Baikal. Dokl. Earth Sci. 2003, 393, 822-826.

7. Kalmychkov, G.V.; Egorov, A.V.; Kuz'min, M.I.; Khlystov, O.M. Genetic types of methane from Lake Baikal. Dokl. Earth Sci 2006, 411, 1462-1465. [CrossRef]

8. Kontorovich, A.E.; Kashirtsev, V.A.; Moskvin, V.I.; Burshtein, L.M.; Zemskaya, T.I.; Kostyreva, E.A.; Kalmychkov, G.V.; Khlystov, O.M. Petroleum potential of Baikal deposits. Russ. Geol. Geophys. 2007, 48, 1046-1053. [CrossRef]

9. Krylov, A.A.; Khlystov, O.M.; Zemskaya, T.I.; Minami, H.; Hachikubo, A.; Shoji, H.; Kida, M.; Pogodaeva, T.; Naudts, L.; Poort, J. Crystallization of Authigenic Carbonates in Mud Volcanoes at Lake Baikal. Geochem. Int. 2008, 46, 985-995. [CrossRef]

10. Tsekhovsky, U.G.; Yapaskurt, O.V. Processes of Cenozoic lithogenesis in the Baikal Rift Zone. Lithol. Mineral. Resour. 2016, $5,448-464$

11. Vologina, E.G.; Sturm, M. Types of Holocene deposits and regional pattern of sedimentation in Lake Baikal. Russ. Geol. Geophys. 2009, 50, 722-727. [CrossRef]

12. Vologina, E.G.; Sturm, M.; Vorobieva, S.S. Modern sedimentation in Lake Baikal. Results of experiments with sedimentation traps. In Proceedings of the XII Ural Lithological Meeting, Ekaterinburg, Russia, 22-26 October 2018; Maslov, A.V., Alexeev, V.P., Mizens, G.A., Talalay, A.G., Sapurin, S.A., Melnichuk, O.Y., Badida, L.V., Eds.; IGG UrO RAN: Ekaterinburg, Russia, 2018 ; p. 384. (In Russian)

13. Zemskaya, T.I.; Lomakina, A.V.; Mamaeva, E.V.; Zakharenko, A.S.; Pogodaeva, T.V.; Petrova, D.P.; Galachyants, Y.P. Bacterial communities in sediments of Lake Baikal from areas with oil and gas discharge. Aquat. Microb. Ecol. 2015, 76, 95-109. [CrossRef]

14. Mats, V.D.; Shcherbakov, D.U.; Efimova, I.M. Late Cretaceous-Cenozoic history of the Lake Baikal depression and formation its unique biodiversity. Stratigr. Geol. Correl. 2011, 19, 404-423. [CrossRef]

15. Parfenova, V.V.; Gladkikh, A.S.; Belykh, O.I. Comparative analysis of biodiversity in the planktonic and biofilm bacterial communities in Lake Baikal. Microbiology 2013, 82, 91-101. [CrossRef]

16. Namsaraev, B.B.; Zemskaya, T.I. Microbiological Processes of Carbon Circulation in Lake Baikal Bottom Sediments; SB RAS Publication: Novosibirsk, Russia, 2000.

17. Pimenov, N.V.; Zakharova, E.E.; Bryukhanov, A.L.; Korneeva, V.A.; Tourova, T.P.; Kuznetsov, B.B.; Pogodaeva, T.V.; Zemskaya, T.I.; Kalmychkov, G.V. Activity and structure of the sulfate-reducing bacterial community in the sediments of the southern part of Lake Baikal. Microbiology 2014, 83, 47-55. [CrossRef]

18. Zemskaya, T.I.; Sitnikova, T.Y.; Kiyashko, S.I.; Kalmychkov, G.V.; Pogodaeva, T.V.; Mekhanikova, I.V.; Naumova, T.V.; Shubenkova, O.V.; Chernitsina, S.M.; Kotsar, O.V.; et al. Faunal communities at sites of gas- and oil-bearing fluids in Lake Baikal. Geo-Mar. Lett. 2012, 32, 437-451. [CrossRef]

19. Zemskaya, T.I.; Bukin, S.V.; Lomakina, A.V.; Pavlova, O.N. Microorganisms of bottom sediments of Baikal-The deepest and most ancient lake in the world. Microbiology 2021, 90, 286-303. [CrossRef]

20. Tissot, B.; Welte, D.H. Petroleum Formation and Occurrence, 2nd ed.; Springer: Berlin/Heidenberg, Germany, 1984.

21. Philp, R.P. Biological markers in fossil fuel production. Mass Spectrometry Rev. 1985, 4, 1-54. [CrossRef]

22. Gupta, N.S.; Briggs, D.E.G.; Collinson, M.E.; Evershed, R.P.; Michels, R.; Jack, K.S.; Pancost, R.D. Evidence for the in situ polymerisation of labile aliphatic organic compounds during the preservation of fossil leaves: Implications for organic matter preservation. Org. Geochem. 2007, 38, 499-522. [CrossRef]

23. Petrova, V.I.; Batova, G.I.; Kursheva, A.V.; Litvinenko, I.V. Geochemistry of organic matter of bottom sediments in the central arctic rises of the Arctic Ocean. Russ. Geol. Geophys. 2010, 51, 88-97. [CrossRef]

24. Golubev, V.A. Sources of subaquaeous discharge and heat balance of North Baikal. Dokl. Earth Sci. 1993, 328, 315-318.

25. Granina, L.Z.; Klerkx, J.; Callender, E.; Leermakers, M.; Golobokova, L.P. Bottom sediments and pore waters near a hydrothermal vent in Lake Baikal (Frolikha Bay). Russ. Geol. Geophys. 2007, 48, 237-246. [CrossRef]

26. Namsaraev, B.B.; Dulov, L.Y.; Dubinina, G.A.; Zemskaya, T.I.; Granina, L.Z.; Karabanov, Y.B. Bacterial synthesis and destruction of organic-matter in microbial mats of Lake Baikal. Microbiology 1994, 63, 193-197.

27. Kaygorodova, I.A. Deep-water fauna of Oligochaeta (Annelida, Clitellata) near a hydrothermal spring of Frolikha Bay, Northern Baikal (East Siberia, Russia). J. Sib. Fed. Univ. Biol. 2011, 2, 117-132. (In Russian)

28. Lomakina, A.V.; Mamaeva, E.V.; Galachyants, Y.P.; Petrova, D.P.; Pogodaeva, T.V.; Shubenkova, O.V.; Khabuev, A.V.; Morozov, I.V.; Zemskaya, T.I. Diversity of archaea in bottom sediments of the discharge area. Geomicrobiol. J. 2018, 35, 50-63. [CrossRef] 
29. Radnaeva, L.D.; Bazarsadueva, S.V.; Taraskin, V.V.; Tulokhonov, A.K. First data on lipids and microorganisms of deepwater endemic sponge Baikalospongia intermedia and sediments from hydrothermal discharge area of the Frolikha Bay (North Baikal, Siberia). J. Great Lakes Res. 2020, 46, 67-74. [CrossRef]

30. Zemskaya, T.I.; Namsaraev, B.B.; Dultseva, N.M.; Khanaeva, T.A.; Golobokova, L.P.; Dubunina, G.A.; Dulov, L.E.; Wada, E. Ecophysiological characteristics of the mat-forming bacterium Thioploca in bottom sediments of the Frolikha Bay, Northern Baikal. Microbiology 2001, 70, 335-341. [CrossRef]

31. Kostyreva, E.A.; Kashirtsev, V.A.; Moskvin, V.I.; Bukin, S.V.; Khabuev, A.V. Organic matter of bottom sediments from the zone hydrothermal activity (Frolikha Bay, North Baykal). In Proceedings of the International Exhibition and Scientific Congress "Interexpo GEO-Siberia", Novosibirsk, Russia, 19-21 May 2019; Kontorovich, A.E., Epov, M.I., Eltsov, I.N., Kondratenko, A.S., Smirnov, M.Y., Nevol'ko, A.I., Eds.; SSUGT: Novosibirsk, Russia, 2019; Volume 2, pp. 81-86. [CrossRef]

32. Khlystov, O.M.; Minami, H.; Hachikubo, A.; Yamashita, S.; De Batist, M.; Nauds, L.; Khabuev, A.V.; Chenskiy, A.G.; Gubin, N.A.; Vorobyeva, S.S. Age of mud breccia from mud volcanoes in Academician Ridge, Lake Baikal. Geodyn. Tectonophys. 2017, mboxemph8, 923-932. [CrossRef]

33. Khlystov, O.M.; Poort, J.; Mazzini, A.; Akhmanov, G.G.; Minami, H.; Hachikubo, A.; Khabuev, A.V.; Kazakov, A.V.; De Batist, M.; Naudts, L.; et al. Shallow-rooted mud volcanism in Lake Baikal. Mar. Pet. Geol. 2019, 102, 580-589. [CrossRef]

34. Belykh, O.I.; Ekaterina, G.; Sorokovikova, T.; Saphonova, A.; Tikhonova, I.V. Autotrophic picoplankton of Lake Baikal: Composition, abundance and structure. Hydrobiologia 2006, 568, 9-17. [CrossRef]

35. Vologina, E.G.; Sturm, M. Particulate fluxes in South Baikal: Evidence from sediment trap experiments. Russ. Geol. Geophys. 2017, 58, 1045-1052. [CrossRef]

36. Khanaeva, T.A.; Zemskaya, T.I.; Bel'kova, N.L.; Khlystov, O.M.; Namsaraev, B.B. Diversity of laboratory-reared prokaryotes in bottom sediments of the Academichesky Ridge, Lake Baikal. Inland Water Biol. 2010, 3, 38-43. [CrossRef]

37. Kontorovich, A.E.; Drobot, D.I.; Presnova, R.N. Geochemistry of naphthides and problem of Baikal oil genesis. Sov. Geol. 1989, 2, 21-29. (In Russian)

38. Delengov, M.T.; Fadeeva, N.P.; Akhmanov, G.G.; Khlystov, O.M. Naphthides of the bottom silts of Lake Baikal of the focused discharge zone of hydrocarbons on the traverse of cape Gorevoy Utes. In Proceedings of the VIII International Conference "Marine Research and Education", Moscow, Russia, 28-31 October 2019; Volume 2.

39. Kashirtsev, V.A.; Kontorovich, A.E.; Moskvin, V.I.; Danilova, V.P.; Melenevsky, V.N. Terpanes from oil shows of Lake Baikal. Pet. Chem. 2006, 46, 217-224. [CrossRef]

40. Khlystov, O.M.; Gorshkov, A.G.; Zemskaya, T.I.; Granin, N.G.; Vorob'eva, S.S.; Pavlova, O.N.; Yakup, M.A.; Makarov, M.M.; Grachev, M.A.; Egorov, A.V.; et al. Oil in the lake of world heritage. Dokl. Earth Sci. 2007, 415, 682-685. [CrossRef]

41. Zakharenko, A.S.; Galachyants, Y.P.; Morozov, I.V.; Shubenkova, O.V.; Morozov, A.A.; Ivanov, V.G.; Pimenov, N.V.; Krasnopeev, A.Y.; Zemskaya, T.I. Bacterial Communities in Areas of Oil and Methane Seeps in Pelagic of Lake Baikal. Microb. Ecol. 2019, 78, 269-285. [CrossRef]

42. Gorshkov, A.; Pavlova, O.; Khlystov, O.; Zemskaya, T. Fractioning of petroleum hydrocarbons from seeped oil as a factor of purity preservation of water in Lake Baikal (Russia). J. Great Lakes Res. 2020, 46, 115-122. [CrossRef]

43. Kashik, S.A.; Isaev, V.P. Generation and emission of methane from bottom sediments of Lake Baikal. Dokl. Earth Sci. 2008 423, 393-396. [CrossRef]

44. Khlystov, O.M.; Zemskaya, T.I.; Sitnikova, T.Y.; Mekhanikova, I.V.; Kaigorodova, I.A.; Gorshkov, A.G.; Timoshkin, O.A.; Shubenkova, O.V.; Chernitsina, S.M.; Lomakina, A.V.; et al. Bottom bituminous constructions and biota inhabiting them according to investigation of Lake Baikal with the mir submersible. Dokl. Earth Sci. 2009, 415, 682-685. [CrossRef]

45. Pavlova, O.N.; Lomakina, A.V.; Gorshkov, A.G.; Suslova, M.Y.; Likhoshvai, A.V.; Zemskaya, T.I. Microbial communities and their ability to oxidize n-alkanes in the area of release of gas- and oil-containing fluids in Mid-Baikal (Cape Gorevoi Utes). Biol. Bull. 2012, 39, 458-463. [CrossRef]

46. Minami, H.; Hachikubo, A.; Sakagami, H.; Yamashita, S.; Soramoto, Y.; Kotake, T.; Takahash, N.; Shoji, H.; Pogodaeva, T.; Khlystov, O.; et al. Sequentially sampled gas hydrate water, coupled with pore water and bottom water isotopic and ionic signatures at the Kukuy mud volcano, Lake Baikal: Ambiguous deep-rooted source of hydrate-forming water. Geo-Mar. Lett. 2014, 34, 241-251. [CrossRef]

47. Khlystov, O.M.; Khabuev, A.V.; Minami, H.; Hachikubo, A.; Krylov, A.A. Gas hydrates in Lake Baikal. Limnol. Freshw. Biol. 2018, 1, 66-70. [CrossRef]

48. Zemskaya, T.I.; Pogodaeva, T.V.; Shubenkova, O.V.; Kalmychkov, G.V.; Pogodaeva, T.V.; Mekhanikova, I.V.; Naumova, T.V.; Shubenkova, O.V.; Chernitsina, S.M.; Kotsar, O.V.; et al. Geochemical and microbiological characteristics of sediments near the Malenky mud volcano (Lake Baikal, Russia), with evidence of Archaea intermediate between the marine anaerobic methanotrophs ANME-2 and ANME-3. Geo-Mar. Lett. 2010, 30, 411-425. [CrossRef]

49. Lomakina, A.V.; Bukin, S.V.; Pogodaeva, T.V.; Ivanov, V.G.; Khalzov, I.A.; Krylov, A.A.; Zemskaya, T.I. Anaerobic oxidation of methane in differences types of geological structures at Lake Baikal. Limnol. Freshw. Biol. 2020, 4, 1000-1003. [CrossRef]

50. Lomakina, A.; Pogodaeva, T.; Kalmychkov, G.; Chernitsyna, S.; Zemskaya, T. Diversity of NC10 bacteria and ANME-2d archaea in sediments of fault zones at Lake Baikal. Diversity 2020, 12, 10. [CrossRef] 
51. Minami, H.; Hachikubo, A.; Yamashita, S.; Sakagami, H.; Kasashima, R.; Konishi, M.; Shoji, H.; Takahashi, N.; Pogodaeva, T.; Krylov, A.; et al. Hydrogen and oxygen isotopic anomalies in pore waters suggesting clay mineral dehydration at gas hydrate bearing Kedr mud volcano, southern Lake Baikal Russia. Geo-Mar. Lett. 2018, 38, 403-415. [CrossRef]

52. Hachikubo, A.; Minami, H.; Yamashita, S.; Khabuev, A.; Krylov, A.; Kalmychkov, G.; Poort, J.; De Batist, M.; Chenskiy, A.; Manakov, A.; et al. Characteristics of hydrate-bound gas retrieved at the Kedr mud volcano (southern Lake Baikal). Nature Research. Sci. Rep. 2020, 10,1-12. [CrossRef]

53. Luzhetsky, V.G. Gas hydrates in the region of Posolskaya Bank of Lake Baikal. In Proceedings of the International Scientific Congress "Interexpo GEO-Siberia", Novosibirsk, Russia, 22-24 April 2008; SSUGT: Novosibirsk, Russia, 2008; Volume 5, pp. 1-6. (In Russian)

54. Bukin, S.V.; Pavlova, O.N.; Manakov, A.Y.; Kostyreva, E.A.; Chernitsyna, S.M.; Mamaeva, E.V.; Pogodaeva, T.V.; Zemskaya, T.I. The ability of microbial community of Lake Baikal bottom sediments associated with gas discharge to carry out the transformation of organic matter under thermobaric conditions. Front. Microbiol. 2016, 7, 1-12. [CrossRef]

55. Chernitsyna, S.M.; Mamaeva, E.V.; Lomakina, A.V.; Pogodaeva, T.V.; Galach'yants, Y.P.; Bukin, S.V.; Khlystov, O.M.; Zemskaya, T.I.; Pimenov, N.V. Phylogenetic Diversity of Microbial Communities of the Posolsk Bank Bottom Sediments, Lake Baikal. Microbiology 2016, 85, 672-680. [CrossRef]

56. Dagurova, O.P.; Namsaraev, B.B.; Kozyreva, L.P.; Zemskaya, T.I.; Dulov, L.E. Bacterial processes of the methane cycle in bottom sediments of Lake Baikal. Microbiology 2004, 73, 202-210. [CrossRef]

57. Morgunova, I.P.; Petrova, V.I.; Litvinenko, I.V.; Kursheva, A.V.; Batova, G.I.; Renaud, P.E.; Granovitch, A.I. Hydrocarbon molecular markers in the Holocene bottom sediments of the Barents Sea as indicators of natural and anthropogenic impacts. Mar. Pollut. Bull. 2019, 149, 1-12. [CrossRef] [PubMed]

58. Morgunova, I.P.; Kursheva, A.V.; Petrova, V.I.; Litvinenko, I.V.; Batova, G.I.; Renaud, P.E.; Maltseva, A.L.; Granovitch, A.I. Natural and anthropogenic organic matter inputs to intertidal deposits of the urbanized Arctic region: A multi-proxy approach. Mar. Chem. 2021, 234, 1-15. [CrossRef]

59. Huang, X.Y.; Jiao, D.; Lu, L.Q.; Xie, S.C.; Huang, J.H.; Wang, Y.B.; Yin, H.F.; Wang, H.M.; Zhang, K.X.; Lai, X.L. The fluctuating environment associated with the episodic biotic crisis during the Permo/Triassic transition: Evidence from microbial biomarkers in Changxing, Zhejiang Province. Sci. China Ser. D Earth Sci. 2007, 50, 1052-1059. [CrossRef]

60. Meredith, W.; Snape, C.E.; Carr, A.D.; Nytoft, H.P.; Love, G.D. The occurrence of unusual hopenes in hydropyrolysates generated from severely biodegraded oil seep asphaltenes. Org. Geochem. 2008, 39, 1243-1248. [CrossRef]

61. Parfenova, T.M.; Pushkarev, M.S.; Ivanova, E.N. Hopanes and hopenes of the Lower Cambrian Synyaya formation (northern slope of the Aldan Anteclise). Dokl. Earth Sci. 2010, 430, 129-133. [CrossRef]

62. $\mathrm{Xu}, \mathrm{H}$.; George, S.C.; Houa, D. Algal-derived polycyclic aromatic hydrocarbons in Paleogene lacustrine sediments from the Dongying Depression, Bohai Bay Basin, China. Mar. Pet. Geol. 2019, 102, 402-425. [CrossRef]

63. Kashirtsev, V.A.; Dzyuba, O.S.; Nikitenko, B.L.; Kostyreva, E.A.; Ivanova, I.K.; Shevchenko, N.P. Geochemistry of high-molecular weight dimethylalkanes. Russ. Geol. Geophys. 2021, 62, 866-877. [CrossRef]

64. Edgington, D.; Klump, J.; Robbins, J.; Kusner, Y.S.; Pampura, V.D.; Sandimirov, I.V. Sedimentation rates, residence times and radionuclide inventories in Lake Baikal from 137Cs and 210Pb in sediment cores. Nature 1991, 350, 601-604. [CrossRef]

65. Gar'kusha, D.N.; Fedorov, Y.A.; Andreev, Y.A.; Tambieva, N.S.; Mikhailenko, O.A. Methane and sulfide sulfur in the bottom sediments of Lake Baikal. Geokhimia 2019, 64, 427-439. [CrossRef]

66. Ferronsky, V.I.; Polyakov, V.A.; Kuprin, P.N.; Vlasova, L.S. Hydrotroilite as a bioindicator of paleohydrological and paleoclimatic processes in the Caspian basin. Water Resour. 2014, 41, 473-487. [CrossRef]

67. Fedorov, Y.A.; Gar'kusha, D.N.; Tambieva, N.S.; Andreev, Y.A.; Mikhailenko, O.A. Influence of the grain size composition of bottom sediments in Lake Baikal on the distribution of methane and sulfide sulfur. Lithol. Mineral. Resour. 2019, 54, 53-65. [CrossRef]

68. Garankina, V.P.; Dambaev, V.B.; Buryukhaev, S.P. Isotope composition of carbon of organic matter of bottom sediments of Lake Baikal. Bull. Buryat State Univ. 2009, 3, 14-17. (In Russian)

69. Bordovskiy, O.K. Accumulation of organic matter in bottom sediments. Mar. Geol. 1965, 3, 3-82. [CrossRef]

70. Romankevich, E.A. Geochemistry of Organic Matter in the Ocean; Springer: Berlin/Heidelberg, Germany, 1984; p. 334. [CrossRef]

71. Geodekyan, A.A.; Ulmishek, G.F.; Tcherova, T.G.; Avilov, V.I.; Bokovoy, A.P.; Verkhovskaya, Z.I.; Fedorova, M.S. Bituminological studies of the samples from site 379 and laboratory simulation of dispersed organic matter transformation. Deep Sea Drill. Proj. Initial Rep. 1978, 42 Pt 2. [CrossRef]

72. Bazhenova, O.K.; Burlin, U.K.; Sokolov, B.A.; Hain, V.E. Geology and Geochemistry of Oil and Gas, 2nd ed.; Moscow University Publishing House, Publishing Center "Akademia": Moskow, Russia, 2004; p. 417. (In Russian)

73. Ficken, K.J.; Li, B.; Swain, D.L.; Eglinton, G. An n-alkane proxy for the sedimentary input of submerged/floating freshwater aquatic macrophytes. Org. Geochem. 2000, 31, 745-749. [CrossRef]

74. Vogts, A.; Moossen, H.; Rommerskirchen, F.; Rullkötter, J. Distribution patterns and stable carbon isotopic composition of alkanes and alkan-1-ols from plant waxes of African rain forest and savanna C3 species. Org. Geochem. 2009, 40, 1037-1054. [CrossRef]

75. Seki, O.; Harada, N.; Sato, M.; Kawamura, K.; Ijiri, A.; Nakatsuka, T. Assessment for paleoclimatic utility of terrestrial biomarker records in the Okhotsk Sea sediments. Deep-Sea Res. II 2012, 61-64, 85-92. [CrossRef]

76. Dembicki, H.; Meinschein, W.G.; Hattin, D.E. Possible ecological and environmental significance of the predominance of even-carbon number C20-C30 n-alkanes. Geochim. Cosmochim. Acta 1976, 40, 203-208. [CrossRef] 
77. Grimalt, J.; Albaiges, J. Predominance of even carbon-numbered n-alkanes in coal seam samples of Nograd Basin (Hungary). Naturwissenschaften 1986, 73, 729-731. [CrossRef]

78. Nishimura, M.; Baker, E.W. Possible origin of n-alkanes with a remarkable even-to-odd predominance in recent marine sediments. Geochim. Cosmochim. Acta 1986, 50, 299-305. [CrossRef]

79. Lein, A.Y.; Makkaveev, P.N.; Savvichev, A.S.; Kravchishina, M.D.; Belyaev, N.A.; Dara, O.M.; Ponyaev, M.S.; Zaharova, E.E.; Rozanov, A.G.; Ivanov, M.V.; et al. The processes of particulate matter transformation from water column to sediment in the Kara Sea. Oceanology 2013, 53, 570-606. [CrossRef]

80. Bourbonniere, R.A.; Meyers, P.A. Sedimentary geolipid records of historical changes in the watersheds and productivities of Lakes Ontario and Erie. Limnol. Oceanogr. 1996, 41, 352-359. [CrossRef]

81. Peters, K.E.; Walters, C.C.; Moldowan, J.M. The Biomarker Guide: Biomarkers and Isotopes in Petroleum Systems and Earth History, 2nd ed.; Cambridge University Press: Cambridge, UK, 2005; Volume 2. [CrossRef]

82. Bouloubassi, I.; Saliot, A. Investigation of anthropogenic and natural organic inputs in estuarine sediments using hydrocarbon markers (NAH, LAB, PAH). Oceanol. Acta 1993, 16, 145-161.

83. Ganeeva, Y.M.; Yusupova, T.N.; Romanov, G.V. Waxes in asphaltenes of crude oils and wax deposits. Pet. Sci. 2016, 13, 737-745. [CrossRef]

84. Pavlova, O.N.; Izosimova, O.N.; Gorshkov, A.G.; Novikova, A.S.; Bukin, S.V.; Ivanov, V.G.; Khlystov, O.M.; Zemskaya, T.I. Current state of deep oil seepage near cape Gorevoy Utes (Central Baikal). Russ. Geol. Geophys. 2020, 61, 1007-1014. [CrossRef]

85. Pavlova, O.N.; Izosimova, O.N.; Chernitsyna, S.M.; Ivanov, V.G.; Pogodaeva, T.V.; Khabuev, A.V.; Gorshkov, A.G.; Zemskaya, T.I. Anaerobic oxidation of petroleum hydrocarbons in enrichment cultures from sediments of the Gorevoy Utes natural oil seep under methanogenic and sulfate-reducing conditions. Microb. Ecol. 2021. [CrossRef]

86. Petrov, A.A. Petroleum Hydrocarbons; Nauka: Moscow, Russia, 1984; p. 263. (In Russian)

87. Ćmiel, S.R.; Fabiańska, M.J. Geochemical and petrographic properties of some Spitsbergen coals and dispersed organic matter. Int. J. Coal Geol. 2004, 57, 77-97. [CrossRef]

88. Van Koeverden, J.H.; Karlsen, D.A.; Schwark, L.; Chpitsglouz, A.; Backer-Owe, K. Oil-prone Lower Carboniferous coals in the Norwegian Barents Sea: Implications for a Palaeozoic petroleum system. J. Pet. Geol. 2010, 33, 155-182. [CrossRef]

89. Shanmugam, G. Significance of coniferous rain forests and related organic matter in generating commercial quantities of oil, Gippsland Basin, Australia. Am. Assoc. Pet. Geol Bull. 1985, 69, 1241-1254. [CrossRef]

90. Pavlova, O.N.; Zemskaya, T.I.; Lomakina, A.V.; Shubenkova, O.V.; Manakov, A.Y.; Moskvin, V.I.; Morozov, I.V.; Bukin, S.V.; Khlystov, O.M. Transformation of organic matter by microbial community in sediments of Lake Baikal under experimental thermobaric conditions of protocatagenesis. Geomicrobiol. J. 2016, 33, 599-606. [CrossRef]

91. Samuel, O.J.; Kildahl-Andersen, G.; Nytoft, H.P.; Johansen, J.E.; Jones, M. Novel tricyclic and tetracyclic terpanes in tertiary deltaic oils: Structural identification, origin and application to petroleum correlation. Org. Geochem. 2010, 41, 1326-1337. [CrossRef]

92. Ageta, H.; Shiojima, K.; Arai, Y. Acid-induced rearrangement of triterpenoid hydrocarbons belonging to the hopane and migrated hopane series. Chem. Pharm. Bull. 1987, 35, 2705-2716. [CrossRef]

93. Damste, J.S.S.; Schouten, S.; Volkman, J.K. C27-C30 neohop-13(18)-enes and their saturated and aromatic derivatives in sediments: Indicators for diagenesis and water column stratification. Geochim. Cosmochim. Acta 2014, 133, 402-421. [CrossRef]

94. Ando, T.; Sawada, K.; Nakamura, H.; Omatsu, K.; Takashima, R.; Nishi, H. Depositional environments and maturity evaluated by biomarker analyses of sediments deposited across the Cenomanian-Turonian boundary in the Yezo Group, Tomamae area, Hokkaido, Japan. Isl. Arc 2017, 26, 1-17. [CrossRef]

95. Damsté, J.S.S.; Van Duin, A.C.T.; Hollander, D.; Kohnen, M.E.L.; De Leeuw, J.W. Early diagenesis of bacteriohopanepolyol derivatives: Formation of fossil homohopanoids. Geochim. Cosmochim. Acta 1995, 59, 5141-5157. [CrossRef]

96. Summons, R.E.; Jahnke, L.L.; Hope, J.M.; Logan, G.A. 2-Methylhopanoids as biomarkers for cyanobacterial oxygenic photosynthesis. Nature 1999, 400, 554-557. [CrossRef]

97. Farrimond, P.; Talbot, H.M.; Watson, D.F.; Schulz, L.K.; Wilhelms, A. Methylhopanoids: Molecular indicators of ancient bacteria and a petroleum correlation tool. Geochim. Cosmochim. Acta 2004, 68, 3873-3882. [CrossRef]

98. Aguiar, A.; Aguiar, H.G.M.; Azevedo, D.A.; Neto, F.R.A. Identification of methylhopane and methylmoretane series in Ceara Basin oils, Brazil, using comprehensive two-dimensional gas chromatography coupled to time-of-flight mass spectrometry. Energy Fuels 2011, 25, 1060-1065. [CrossRef]

99. Damsté, J.S.S.; Kenig, F.; Koopmans, M.P.; Köster, J.; Schouten, S.; Hayes, J.M.; Leeuw, J.W. Evidence for gammacerane as an indicator of water column stratification. Geochim. Cosmochim. Acta 1995, 59, 1895-1900. [CrossRef]

100. Takishita, K.; Chikaraishi, Y.; Leger, M.M.; Kim, E.; Yabuki, A.; Ohkouchi, N.; Roger, A.J. Lateral transfer of tetrahymanolsynthesizing genes has allowed multiple diverse eukaryote lineages to independently adapt to environments without oxygen. Biol. Direct 2012, 7, 1-7. [CrossRef]

101. Santos Neto, E.V.; Hayes, J.M.; Takaki, T. Isotopic biogeochemistry of the Neocomian lacustrine and Upper Aptian marineevaporitic sediments of the Potiguar Basin, Northeastern Brazil. Org. Geochem. 1998, 28, 361-381. [CrossRef]

102. Morgunova, I.P.; Semenov, P.B.; Krylov, A.A.; Kursheva, A.V.; Litvinenko, I.V.; Malyshev, S.A.; Minami, H.; Hachikubo, A.; Zemskaya, T.I.; Khlystov, O.M. Hydrocarbon molecular markers in bottom sediments of fluid discharge zones of Lake Baikal. Neftegazov. Geologia. Teor. Pract. 2018, 13, 1-25. (In Russian) [CrossRef] 
103. Pancost, R.D.; Damsté, J.S.S.; de Lint, S.; van der Maarel, M.J.; Gottschal, J.C. Biomarker evidence for widespread anaerobic methane oxidation in Mediterranean sediments by a consortium of methanogenic archaea and bacteria. The Medinaut Shipboard Scientific Party. Appl. Environ. Microbiol. 2000, 66, 1126-1132. [CrossRef] [PubMed]

104. Simoneit, B.R.T.; Grimalt, J.O.; Wang, T.G.; Cox, R.E.; Hatcher, P.G.; Nissenbaum, A. Cyclic terpenoids of contemporary resinous plant detritus and of fossil woods, ambers and coals. Org. Geochem. 1986, 10, 877-889. [CrossRef]

105. Jiang, C.; Alexander, R.; Kagi, R.I.; Murray, A.P. Origin of perylene in ancient sediments and its geological significance. Org. Geochem. 2000, 31, 1545-1559. [CrossRef]

106. Marynowski, L.; Smolarek, J.; Bechtel, A.; Philippe, M.; Kurkiewicz, S.; Simoneit, B.R.T. Perylene as an indicator of conifer fossil wood degradation by wood-degrading fungi. Org. Geochem. 2013, 59, 143-151. [CrossRef]

107. Wakeham, S.G.; Canuel, E.A. Biogenic polycyclic aromatic hydrocarbons in sediments of the San Joaquin River in California (USA), and current paradigms on their formation. Environ. Sci. Pollut. Res. 2016, 23, 10426-10442. [CrossRef]

108. Hanson, J.R. The aromatisation of terpenes and steroids by dehydrogenation. J. Chem. Res. 2015, 39, 127-133. [CrossRef]

109. Douglas, A.G.; Mair, B.J. Sulfur: Role in Genesis of Petroleum. Science 1965, 147, 499-501. [CrossRef]

110. Hossain, H.M.Z.; Sampei, Y.; Hossain, Q.H.; Roser, B.P.; Sultan-Ul-Islam, M.D. Characterization of alkyl phenanthrene distributions in Permian Gondwana coals and coaly shales from the Barapukuria Basin, NW Bangladesh. Res. Org. Geochem. 2013, 29, 17-28. [CrossRef]

111. Pavlova, O.N.; Bukin, S.V.; Kostyreva, E.; Moskvin, V.I.; Manakov, A.Y.; Morozov, I.V.; Galachyants, Y.P.; Khabuev, A.V.; Zemskaya, T.I. Experimental transformation of organic matter by the microbial community from the bottom sediments of Akademichesky Ridge (Lake Baikal). Russ. Geol Geophys. 2019, 60, 926-937. [CrossRef]

112. Popovskaya, G.I. Ecological monitoring of phytoplankton in Lake Baikal. Aquat. Ecosyst. Health Manag. 2000, 3, 215-225. [CrossRef]

113. Zhang, L.; Huang, D.; Liao, Z. High concentration retene and methylretene in Silurian carbonate of Michigan Basin. Chin. Sci. Bull. 1999, 44, 2083-2086. [CrossRef]

114. Romero-Sarmiento, M.-F.; Riboulleau, A.; Vecoli, M.; Versteegh, G. Occurrence of retene in upper Silurian-lower Devonian sediments from North Africa: Origin and implications. Org. Geochem 2010, 41, 302-306. [CrossRef]

115. Ciobanu, M.-C.; Burgaud, G.; Dufresne, A.; Breuker, A.; Rédou, V.; Maamar, S.B.; Gaboyer, F.; Vandenabeele-Trambouze, O.; Lipp, J.S.; Schippers, A.; et al. Microorganisms persist at record depths in the subseafloor of the Canterbury Basin. ISME J. 2014, 8, 1370-1380. [CrossRef]

116. Gorshkov, A.G.; Izosimova, O.N.; Kustova, O.V.; Marinaite, I.I.; Galachyants, Y.P.; Sinyukovich, V.N.; Khodzher, T.V. Wildfires as a Source of PAHs in Surface Waters of Background Areas (Lake Baikal, Russia). Water 2021, 13, 2636. [CrossRef]

117. Kashirtsev, V.A.; Sovetov, Y.K.; Kostyreva, E.A.; Melenevskii, V.M.; Kuchkina, A.Y. New homologous series of biomarker molecules from Vendian deposits of the Sayan-adjacent Biryusa area. Russ. Geol. Geophys. 2009, 50, 541-545. [CrossRef]

118. Kashirtsev, V.A.; Dolzhenko, K.V.; Fomin, A.N.; Kontorovich, A.E.; Shevchenko, N.P. Hydrocarbon composition of bitumen from deeply buried terrestrial organic matter (zone of apocatagenesis). Russ. Geol. Geophys. 2017, 5, 702-710. [CrossRef]

119. Schouten, S.; Hopmans, E.C.; Pancost, R.D.; Damsté, J.S.S. Widespread occurrence of structurally diverse tetraether membrane lipids: Evidence for the ubiquitous presence of low-temperature relatives of hyperthermophiles. Proc. Natl. Acad. Sci. USA 2000, 97, 14421-14426. [CrossRef]

120. Krylov, A.; Khlystov, O.; Zemskaya, T.; Minami, H.; Hachikubo, A.; Nunokawa, Y.; Kida, M.; Shoji, H.; Naudts, L.; Poort, J.; et al. First discovery and formation process of authigenic siderite from gas hydrate-bearing mud volcanoes in fresh water: Lake Baikal, eastern Siberia. Geophys. Res. Lett. 2008, 35, 1-6. [CrossRef]

121. Krylov, A.A.; Khlystov, O.M.; Hachikubo, A.; Minami, H.; Nunokawa, Y.; Shoji, H.; Zemskaya, T.I.; Naudts, L.; Pogodaeva, T.V.; Kida, M.; et al. Isotopic composition of dissolved inorganic carbon in subsurface sediments of gas hydrate-bearing mud volcanoes, Lake Baikal: Implications for methane and carbonate origin. Geo-Mar. Lett. 2010, 30, 427-437. [CrossRef]

122. Braids, O.C.; Miller, R.H. Fats, waxes, and resins in soil. In Soil Components; Gieseking, J., Ed.; Springer: New York, NY, USA, 1975; Volume 1, pp. 343-368. [CrossRef]

123. Wu, Q.; Schleuss, U.; Blume, H.-P. Investigation on soil lipid extraction with different organic solvents. J. Plant. Nutr. Soil Sci. 1995, 158, 347-350. [CrossRef]

124. Fuchsman, C.H. Peat, Industrial Chemistry and Technology; Academic Press: New York, NY, USA, 1980; p. 279.

125. Petrova, V.I.; Batova, G.I.; Kursheva, A.V.; Litvinenko, I.V.; Morgunova, I.P. Molecular geochemistry of organic matter of Triassic rocks in the northeastern part of the Barents Sea: The influence of tectonic and magmatic processes. Russ. Geol. Geophys. 2017, 58, 322-331. [CrossRef]

126. Bukin, S.V.; Pavlova, O.N.; Kalmychkov, G.V.; Ivanov, V.G.; Pogodaeva, T.V.; Galach'yants, Y.P.; Bukin, Y.S.; Khabuev, A.V.; Zemskaya, T.I. Substrate specificity of methanogenic communities from Lake Baikal bottom sediments associated with hydrocarbon gas discharge. Microbiology 2018, 87, 549-558. [CrossRef]

127. Conrad, R.; Claus, P.; Casper, P. Stable isotope fractionation during the methanogenic degradation of organic matter in the sediment of an acidic bog lake, Lake Grosse Fuchskuhle. Limnol. Oceanogr. 2010, 55, 1932-1942. [CrossRef]

128. Liu, Y.; Conrad, R.; Yao, T.; Gleixner, G.; Claus, P. Change of methane production pathway with sediment depth in a lake on the Tibetan plateau. Palaeogeogr. Palaeoclim. Palaeoecol. 2017, 474, 279-286. [CrossRef]

129. Namsaraev, B.B.; Dulov, L.E.; Sokolova, E.N.; Zemskaya, T.I. Bacterial methane production in Lake Baikal bottom sediments. Mikrobiologiya 1995, 64, 411-417. 